\title{
WestVirginiaUniversity
}

THE RESEARCH REPOSITORY @ WVU

Graduate Theses, Dissertations, and Problem Reports

2003

\section{Teachers' perceptions of communicative language teaching use in Brazil}

Marina Bandeira Aleixo

West Virginia University

Follow this and additional works at: https://researchrepository.wvu.edu/etd

\section{Recommended Citation}

Aleixo, Marina Bandeira, "Teachers' perceptions of communicative language teaching use in Brazil" (2003). Graduate Theses, Dissertations, and Problem Reports. 719.

https://researchrepository.wvu.edu/etd/719

This Thesis is protected by copyright and/or related rights. It has been brought to you by the The Research Repository @ WVU with permission from the rights-holder(s). You are free to use this Thesis in any way that is permitted by the copyright and related rights legislation that applies to your use. For other uses you must obtain permission from the rights-holder(s) directly, unless additional rights are indicated by a Creative Commons license in the record and/ or on the work itself. This Thesis has been accepted for inclusion in WVU Graduate Theses, Dissertations, and Problem Reports collection by an authorized administrator of The Research Repository @ WVU. For more information, please contact researchrepository@mail.wvu.edu. 


\title{
Teachers' Perceptions of Communicative Language Teaching Use in Brazil
}

\author{
Marina Bandeira Aleixo \\ Thesis submitted to the \\ Eberly College of Arts and Sciences \\ at West Virginia University \\ in partial fulfillment of the requirements \\ for the degree of \\ Masters of Arts \\ in \\ Foreign Languages
}

\author{
María J. Amores, Ph.D., Chair \\ Susan M. Braidi, Ph.D. \\ Dara G. Shaw, Ed.D.
}

Department of Foreign Languages
Morgantown, West Virginia 2003

Keywords: CLT, Brazil, Teacher Perceptions, EFL, ESL, Training, Class Size, Authentic Materials Copyright 2003 Marina Bandeira Aleixo 


\begin{abstract}
Teachers' Perceptions of Communicative Language Teaching Use in Brazil Marina Bandeira Aleixo
\end{abstract}

Communicative Language Teaching (CLT) has been extensively discussed and researched. However little appears in the literature about CLT use in EFL environments, such as Brazil. Few studies explore CLT adaptation in EFL environments, and if they do, such studies are mostly in Asian countries (Li, 1998; Burnaby \& Sun, 1998). This research investigates CLT use in high schools and language institutes in Southern Brazil. The data consists of written questionnaires, class observations, and in-depth interviews with teachers. Results showed that there are two main problems with CLT use in Brazil. One relates to the various constraints that exist in each of the different settings in which teaching occurs. Another relates to teachers' awareness of CLT principles, and the lack of training in how to appropriately implement such principles in the classroom. 


\section{Acknowledgements}

First, I would like to express my appreciation and thanks to my parents who have always supported me in all my dreams. They have both taught me the value of an academic education, and have always encouraged me to pursue my goals.

Second, I would like to thank my sister, Sabina, and my brother, Pedro. Their love and support has meant the world to me. Finally, I would like to thank my brother-in-law, Pulido, for always cheering me up.

I would also like to thank and express my gratitude for the committee members whom I had the privilege to work with through this process. Dr. Amores, for her words of encouragement, speedy feedback, and for always being there when I needed help. I would also like to thank Dr. Amores for her interest and dedication to this project. Dr. Braidi, for her wonderful tips, and endless patience with my project. Dr. Shaw for her support and help throughout both my thesis and my experience at WVU. Dr. King, for helping me resolve an important situation at WVU. I want to also thank all the participants in the study for their time and commitment.

I would also like to thank my professors, at both WVU and Bluffton College, for sharing their knowledge with me. I have found that they have been a source of inspiration and support throughout my academic career.

Finally I would like to thank my fiancé, Umar who always believed in me. His encouragement, support, and patience throughout this process showed me he is ready to deal with the rest of our future together. I would not have made it without his love and understanding. 
Dedication

To my parents, José and Maria, my sister, Sabina, my brother, Pedro, my grandparents Oswaldo, Vicência, Salvador, and Maria, my brother-in-law, Pulido, and my beloved Umar. 


\section{Table of Contents}

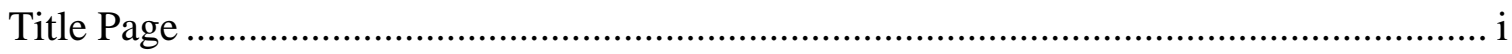

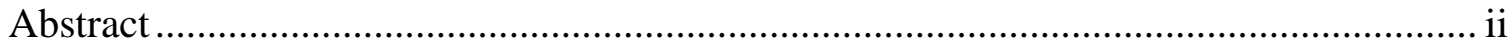

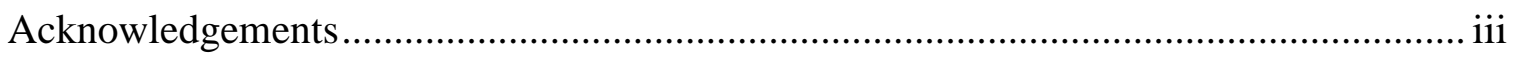

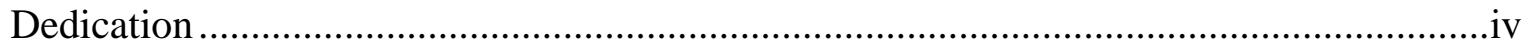

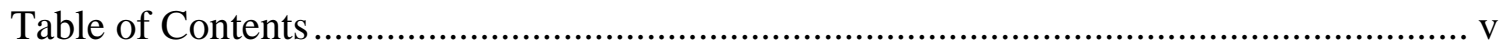

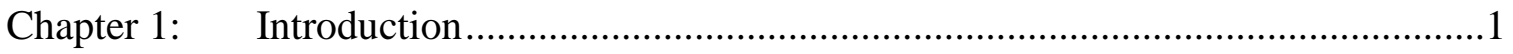

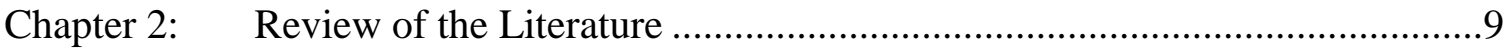

Defining Communicative Language Teaching .............................................

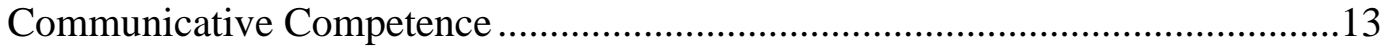

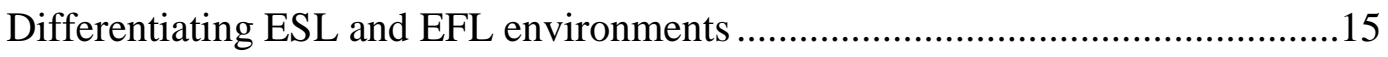

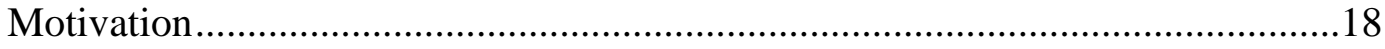

Use of CLT in EFL settings ....................................................................20

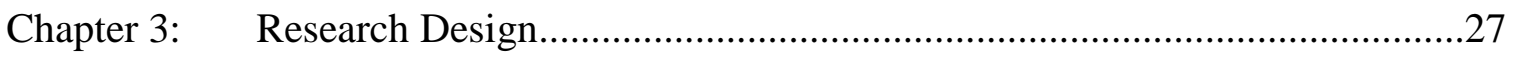

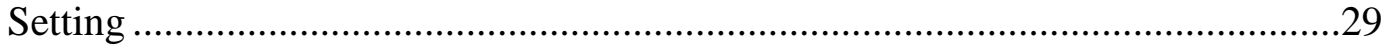

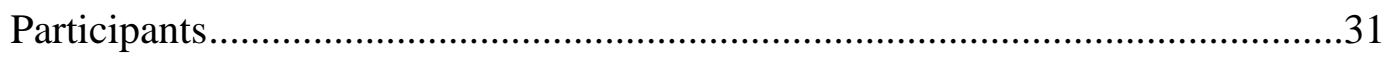

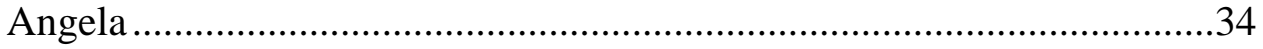

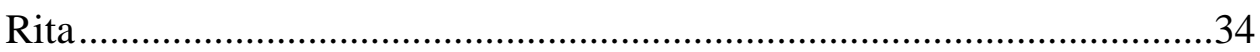

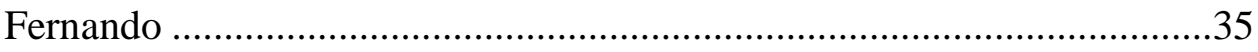

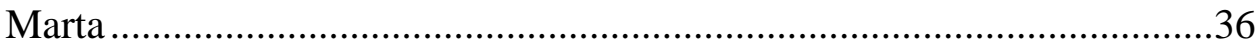

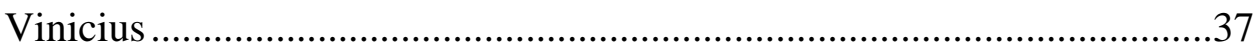

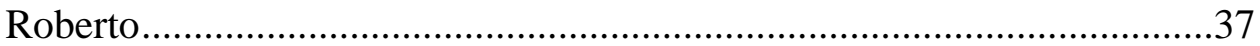


Anita. .38

Procedures .39

Questionnaires. .40

Observations

Interviews

Data Analysis .42

Chapter 4: Findings.....

Introduction

Teachers' awareness of CLT principles.

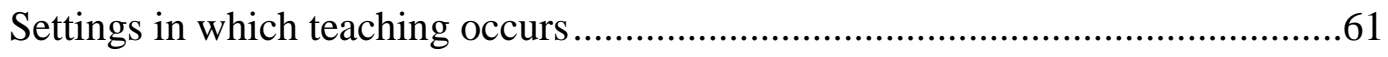

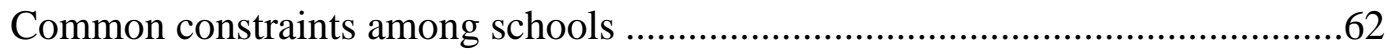

Constraints in high schools ........................................................64

Constraints in the language institutes ............................................ 72

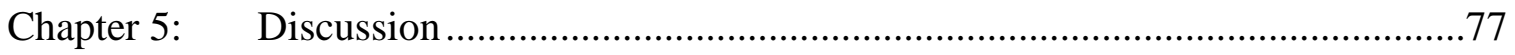

Teachers' awareness of CLT principles ...................................................... 77

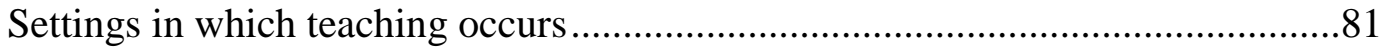

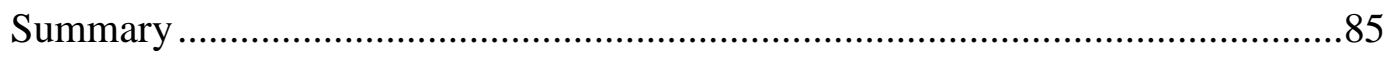

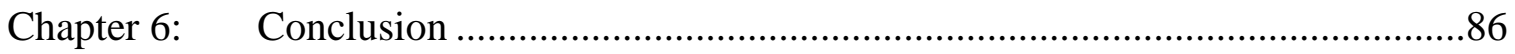

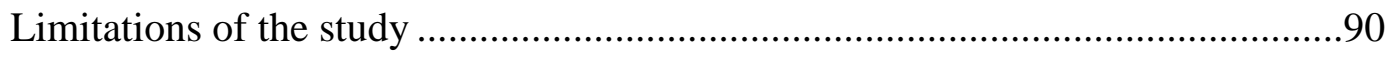

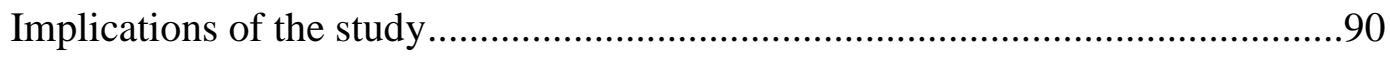

Further research ............................................................................. 91

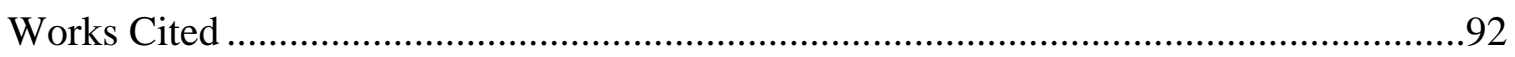


Appendix A: Questionnaire

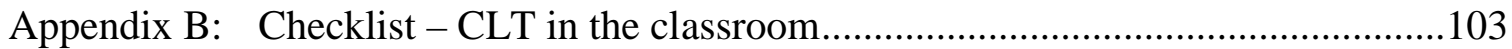

Appendix C: Teacher Interview Questions ....................................................... 104 


\section{Chapter 1}

Introduction

Regardless of successive educational reforms and curriculum

changes, teachers' attitudes and beliefs remain the single strongest guiding influence on instruction (Gorsuch 2000, p. 678).

Communicative Language Teaching (CLT) has its roots in England, which is a primarily English as a Second Language (ESL) environment. In the early 1960s concepts about second language teaching were changing, and the theoretical assumptions behind them were also being rethought. It was during this time of reevaluation that CLT was born. This approach quickly spread in the western countries, until finally it gained popularity among language teachers around the world. Once CLT began its journey across the West, it took many different shapes and forms. It has been almost three decades, and still linguists discuss its theory and models. Some may say that a strong aspect of this teaching approach is its ability to develop and change according to each country's own situation. Nevertheless, there are some general assumptions concerning the term CLT.

According to Richards and Rodgers (2001), CLT begins with a theory of language as communication, which focuses on developing learners' communicative competence. The term communicative competence is best described as "the ability of classroom language learners to interact with other speakers, to make meaning, as distinct from their ability to recite dialogs or perform on discrete-point tests of grammatical knowledge" (p. 16). The focus on communicative competence involves many aspects of the widely known language skills, which are reading, writing, speaking, and listening. 
In previous approaches to language teaching, the role of learners in the development of these skills relied primarily on the teacher. However, with CLT the roles of both the teacher and the learner have been altered. Savignon (2001) states that "there is a general acceptance of the complexity and interrelatedness of skills in both written and oral communication and of the need for the learner to have the experience of communication, to participate in the negotiation of meaning" (p. 15). As the role of the learner has become more active in language learning, the role of the teacher has become more passive. In the CLT approach, the teacher has the role of facilitator of communication and independent participant (Breen \& Candlin, 1980). This moves the focus of the classroom from teacher-centered to student-centered. This represents a unique aspect of CLT, which is a "learner-centered and experience-based view of second language teaching" (Richards and Rodgers, 1986, p. 69). Therefore, teachers are expected to develop and use authentic materials that meet the needs of their particular class. In addition, teachers need to motivate students, and provide them with a comfortable environment for language learning. Littlewood (1981) adds that teacher roles in CLT include, guide of student' learning, coordinator and manager of activities, language instructor, provider of new language, advisor when necessary, and participant. What kinds of demands does CLT put on teachers? More specifically, what kinds of demands does CLT put on EFL teachers, working with students in non-English speaking countries where authentic materials are hard to find?

An approach that was designed with learners primarily in an ESL environment presents difficulties when incorporated into instruction in non-western countries (Burnaby and Sun, 1989; Gorsuch, 2000; Li, 1998; Tarvin and Al-Arish, 1991). The 
main reason for this may be that non-western countries have a primarily English as a Foreign Language (EFL) environment. It is important to make a clear distinction between ESL and EFL. ESL instruction happens inside an English-speaking country; therefore, the environment is rich in opportunities for the learner to test (i.e., use) the target language outside of class. In fact, the ESL environment makes language-learning necessary as part of daily survival. Therefore, every level of learner can acquire the target language both inside and outside the classroom environment. On the other hand, EFL instruction takes place in non-English speaking countries. In this type of environment the learner's only opportunity for exposure to the target language may be the classroom. The teacher and fellow classmates become the only source of the target language. In this situation, motivation depends on the teacher's initiative and the students' desire to acquire the target language. Thus, providing language experience and using authentic materials becomes more of a challenge for teachers. Ellis (1996) explains:

"ESL teaching is primarily designed to develop communicative competence, with little or no curricular demands and pressures of examinations..., [whereas] EFL is part of the school curriculum, and therefore subject to contextual factors such as...teacher's language proficiency, teaching resources, the availability of suitable materials, and may or may not test communicative competence..." (p. 215).

In most countries foreign language tests are grammar- based, contradicting the principals of CLT, thus the learner can become frustrated with a teachers' focus on communicative skills rather than on grammar and form. 
Much of the research in the area of CLT acceptance and use in EFL environments focuses on Asian countries (Burnaby and Sun, 1989; Deckert, 1987; Ellis, 1996; Li, 1998; Xiaoju, 1984). Little is written about teachers' perceptions of CLT in Latin American countries. Latin American countries make up a large number of the EFL world learners, and need to be given attention. The teaching approach in Latin America, like most of the world, is largely influenced by the western styles of language teaching. This study attempts to fill the gap of existing research on teachers' perceptions of CLT in EFL countries, giving special attention and focus to Brazil, the largest Latin American country and the only one where Portuguese is spoken.

Gomes de Matos (1968) reported that English was the most taught foreign language in Brazil, in both private and public high schools, and private language schools. Even though much has changed about language teaching in Brazil over the past two decades, English continues to be the predominant foreign language. Also, aspects of language teaching have developed, such as the focus on a communicative-oriented methodology rather than on grammar-translation. Teachers in Brazil have started to realize the need for communicative competence, and various institutions have provided workshops and training sessions on CLT (Gomes de Matos \& Pinto, 2000).

However, the university entrance exam has continued to influence foreign language teaching in Brazil. The exam has moved from testing grammar to testing reading comprehension. This shift was the result of the publication in 1997 from the Ministry of Education's guidelines for foreign language teaching (Celani \& Lopes, 1997). According to this document, communicative competence is unnecessary for students since they will be unable to use it in a social context. The documents adds that reading 
should be emphasized because it's what the university entrance exams are testing, and what students will need for their higher education. Furthermore, this document explains that classes added to the school curriculum should be determined by their use in society, thus foreign language study doesn't seem relevant, with exception of Spanish and a few other colonial languages that still exist in regions of Brazil, for example German, Italian, and Japanese. Although the document expresses the importance of foreign language as a tool for students to develop life experience, it moves foreign language teaching away from CLT. In fact, in one section it addresses the issue by saying the schools are neither equipped, nor have conditions to implement communicative activities. The Ministry of Education national curriculum is a significant document, and explains the shift to a reading methodology in high schools (Celani \& Lopes, 1997).

The Brazilian teachers of English who participated in this study had conflicting views of the influence of the university examination. Angela stated that "students need reading because that is what the university exam requires, and they want to pass." On the other hand, Rita remarked "pressures to pass the exam is not as important as it was before...it's important but it doesn't influence the material or the way I teach." Fernando also had a contrasting opinion on the issue. He explained that "they are making the English entrance exam so hard and the Spanish exam so easy, that many students are opting for the Spanish test... also with the MERCOSUL, Mercado Comum do Sul, [A common wealth trade between Brazil and other Spanish speaking countries ( Argentina, Uruguay, and Paraguay) in South America] Spanish has been competing with English even at schools." It is important to note that for the university entrance exam, students 
have to take a foreign language test, however they can choose from a number of languages, including English, Spanish, Italian, and German.

Other issues presented in Gomes de Matos and Pinto's (2000) article reflect the changing situation of English teaching in Brazil. Significant aspects, also noted in this study, were teacher training and professional development opportunities. "Only a relatively small number of Brazilian teachers of English are able to obtain a graduate education in English language teaching or in applied linguistics and English language teaching and related areas" (Gomes de Matos \& Pinto, 2000, p. 27). The participants in the study expressed that they participated in many workshops, and seminars related to English language teaching. However, as Vinicius remarked, "they teach you theory and not practice, so when you go into the classroom you are lost and don't now how to put those theories into practice."

The issue of training and understanding of CLT has also been addressed in other studies that focused on CLT in EFL settings (Burnaby and Sun, 1989; Gorsuch, 2000; Li, 1998). Li (1998) reported that teachers in South Korea had a difficult time trying to use CLT because they lacked appropriate training. In addition, Burnaby and Sun (1989) also reported that training was a major concern of teachers in China. Although these studies report CLT limitations for teachers in EFL environments, none address such issues in Brazil.

The intent of this research is to contribute to and inform the foreign language teaching field in Brazil. In some way, I hope to help teachers understand the situation of CLT use in its present condition. CLT is a widely recognized language teaching approach, and it is present in Brazil's high schools and private language schools. 
Therefore, it is important to analyze how it is being used, and what types of problems and benefits it has in such environments. The goal of this study is to give professionals in the field of language teaching insight into the situation in Brazil, by focusing on teachers' perceptions of CLT in Brazil.

A qualitative research design was chosen because the main research question deals with perceptions of teachers, thus relying on personal experiences. "Qualitative research is pragmatic, interpretive, and grounded in the lived experiences of people" (Marshall \& Rossman, 1999, p. 2). Therefore, the experiences of teachers are the main source of information for this study. In addition, qualitative research takes into account the context and setting in which such experienced are lived (Marshall \& Rossman, 1999). Qualitative researchers are characterized as "intrigued with the complexity of social interactions as expressed in daily life and with the meanings the participants themselves attribute to these interactions" (Marshall \& Rossman, 1999, p. 2). Therefore, qualitative research explores social phenomena, and aims to describe in detail such phenomena, according to participants' views. In addition, this type of research draws "on multiple methods of inquiry" (p. 2), to validate data and guarantee credibility of findings. In this study the researcher used three sources of data: written questionnaires with direct and open-ended questions, class observations, and in-depth interviews with teachers. According to the concept of qualitative research, the methods for gathering data include: researcher participation in the setting, observations, interviews, and analysis of documents and materials (p. 105). Given the purpose of the study, qualitative research seemed to be the best and most appropriate research methodology to be used. 
The present chapter has included a general introduction to the study. Chapter 2 provides the review of the literature, containing background information on CLT and communicative competence, a detailed description of EFL and ESL settings, and a review of related studies on the topic of CLT use in EFL environments. Chapter 3 presents the research design. In this chapter a detailed account of information gathering methods, and the research method is described. In Chapter 4 the data collection and analysis of this data are presented. Chapter 5 presents the discussion, in which the data are interpreted and discussed. In this chapter implications of the present research are also discussed. Chapter 6 is the conclusion, which gives a brief summary of the present research study, and provides suggestions for future studies in the area of CLT in EFL setting. 


\section{Chapter 2}

\section{Review of the Literature}

Much effort has been put into research on and discussion of the implementation of Communicative Language Teaching (CLT) in English as a Foreign Language (EFL) countries (Burnaby \& Sun, 1989; Deckert, 1987; Ellis, 1996; Li, 1998; Xiaoju, 1984). Most of these studies focus on the problems teachers face when trying to use CLT. In fact, research has clearly demonstrated that many of the problems in EFL countries are related to the educational system and classroom environment (Burnaby \& Sun, 1989; Gorsuch, 2000; Li, 1998). Other problems relate to the teachers' and learners' ability to adequately use CLT. Since EFL teaching occurs in countries that are non-English speaking, solutions for these problems cannot be imported from ESL countries. It is important to identify the distinction between English as a Foreign Language (EFL) and English as a Second Language (ESL), and to recognize the additional challenges teachers have to deal with in EFL environments.

This chapter will define CLT according to authors in the field of language teaching and learning. Then, a review of existing literature related to communicative competence and how it functions in CLT will be presented. Furthermore, the chapter will examine the impact that ESL and EFL contexts have on the implementation of CLT methodology. Finally, this chapter will also present a description of studies that are directly related to the research topic, and deal with elements of the research question.

\section{Defining Communicative Language Teaching}

Since its introduction in the early 1970s, CLT has been a topic of discussion among many scholars in the field of language teaching. There have been excellent 
chapters and books written in an attempt to define and capture the characteristics of CLT (Canale, 1983; Celce-Murcia, 2001; Cook, 1991; Howatt, 1984; Lee \& VanPatten, 1995; Littlewood, 1981; Morley, 1984; O’Malley \& Chamot, 1990; Richards \& Rodgers, 2001; Richards \& Schmidt, 1983; Rivers, 1968 \& 1978; Savignon, 1997; Savignon, 1983; Scarcella \& Oxford, 1992). Other authors have written various articles and reports on CLT and its main elements of communicative competence (Canale \& Swain, 1980; Celce-Murcia, Dornyei, \& Thurrell, 1997; Fotos, 1994; Hymes, 1972; McGroarty, 1984; Rivers, 1968; Savignon, 1991; Xiaoju, 1984). Although experts may present different versions of what CLT is and how it functions, there are a few general concepts that are agreed upon. CLT is defined by Richards, et al. (1992) in the Dictionary of Language Teaching and Applied Linguistics as "an approach to foreign or second language teaching which emphasizes that the goal of language learning is communicative competence" (p. 65). Although this is a simplified definition, it presents the main concept of CLT, which is the focus on developing communicative competence among learners. Other authors in the field have defined and characterized CLT in various ways (Howatt, 1984; Littlewood, 1981; Richards \& Rodgers, 2001; Savignon, 1991; Scarcella \& Oxford, 1992). Littlewood (1981) explains that "one of the most characteristic features of communicative language teaching is that it pays systematic attention to functional as well as structural aspects of language, combining these into a more fully communicative view" (p. 1). CLT advocates go beyond teaching grammatical rules of the target language, and propose that, by using the target language in a meaningful way, learners will develop communicative competence. 
Richards and Rodgers (2001) state that CLT was a response to the language teaching styles of the 1970s, which focused mainly on grammar. In addition, Richards and Rodgers say that "the communicative approach in language teaching starts from a theory of language as communication" (p. 159). Thus, the communicative approach encourages learners to communicate in a meaningful way using the target language from the very beginning. Accuracy is important; however, communication takes precedence. Therefore, if messages are understood, accuracy may be dealt with later. Richards and Rodgers (2001) also explain that "the emphasis in communicative language teaching on the processes of communication, rather than mastery of language forms, leads to different roles for learners from those found in more traditional second language classrooms" (p. 166). Learners are described as active participants in the language learning process. As a result, CLT also alters the role of the teacher. According to Breen and Candlin (1980), "the teacher has two main roles: the first role is to facilitate the communication process between all participants in the classroom, and between these participants and the various activities and texts. The second role is to act as an independent participant within the learningteaching group" (p. 99). Therefore, due to the different roles of the teacher, when teachers consider implementing CLT, it is important to consider the different teaching environments. A literature review of the appropriateness of CLT for different teaching environments will be given later in this chapter.

Other aspects of CLT are given by Savignon (1991), who states that "communicative language teaching has become a term for methods and curricula that embrace both the goals and the processes of classroom learning, for teaching practice that views competence in terms of social interaction" (p. 263). CLT provides learners with the 
opportunity to experience language through communicative activities. Finally, Howatt (1984) presents the idea that there are two versions of CLT. He states:

There is, in a sense, a 'strong' version of the communicative approach and a 'weak' version. The weak version, which has become more or less standard practice in the last ten years, stresses the importance of providing learners with opportunities to use their English for communicative purposes and, characteristically, attempts to integrate such activities into a wider programme of language teaching. In order to avoid the charge that communicative activities are merely side-shows, efforts are made to ensure that they relate to the purposes of the course as specified in the syllabus, hence the importance of proposals to include semantic as well as purely structural features in a syllabus design... The 'strong' version of communicative teaching, on the other hand, advances the claim that language is acquired through communication, so that it is not merely a question of stimulating the development of the language system itself. If the former could be described as 'learning to use' English, the latter entails 'using English to learn it' (p. 279).

Although the above authors present different aspects of CLT, there is overwhelming agreement that CLT is directly connected to developing communicative competence. The authors concur that CLT has as its primary objective to help students develop communicative competence in the target language. So one may ask "what is communicative competence?" The following section will review a few common conceptualizations of this term. 


\section{Communicative Competence}

Communicative Competence has been defined by Savignon (1997) as "functional language proficiency; the expression, interpretation, and negotiation of meaning involving interaction between two or more persons belonging to the same (or different) speech community" (p. 272). In addition, Savignon characterizes communicative competence as having the following elements:

1. Communicative competence is a dynamic rather than a static concept. It depends on the negotiation of meaning between two or more people who share to some degree the same symbolic system...

2. Communicative competence applies to both written and spoken language, as well as to many other symbolic systems.

3. Communicative competence is context specific. Communication takes place in an infinite variety of situations, and success in a particular role depends on one's understanding of the context and on prior experience of a similar kind...

4. There is a theoretical difference between competence and performance. Competence is defined as a presumed underlying ability and performance as the overt manifestation of that ability. Competence is what one knows. Performance is what one does.

5. Communicative competence is relative, not absolute, and depends on the cooperation of all the participants (p. 14-15).

Savignon has investigated and written extensively on communicative competence, and in most of her work is recognized and accepted by the field. However, it was Canale 
and Swain (1980) who created a more detailed framework for communicative competence. They introduced the four-area framework of knowledge and skill related to communicative competence. According to Canale and Swain (1980), communicative competence involves grammatical competence, sociolinguistic competence, discourse competence, and strategic competence.

Canale (1983) explains that grammatical competence "focuses directly on the knowledge and skill required to understand and express accurately the literal meaning of utterances" (p. 7). Sociolinguistic competence represents the learner's ability to use the language appropriately in social contexts. Therefore sociolinguistic competence shows the learners' ability to go beyond the literal meaning of utterances and recognize what is the intent of such utterances in particular social situations. Canale adds, "sociolinguistic competence is crucial in interpreting utterances for their "social meaning"' (p. 8).

Discourse competence relates to the learner's ability to combine grammatical forms and meaning in an appropriate order for different genre requirements. Discourse competence brings to our attention that learners must also be aware of the discourse patterns of the language they are learning. Strategic competence relates to the learner's ability to master verbal and non-verbal communication strategies. Canale explains that such strategies may be needed for two main reasons: "to compensate for breakdowns in communication due to limiting conditions in actual communication or to insufficient competence in one or more of the other areas of communicative competence, and to enhance the effectiveness of communication" (p. 10). Strategic competence helps the learner continue conversation flow. Learners in beginning stages may find that strategic competence can help them communicate even with their limited vocabulary. 
It is important to acknowledge that communicative competence is central to CLT, and thus requires teachers to be aware of its many aspects. In this study, CLT is defined as an approach that has the aim to develop the learner's communicative competence, and that communicative competence represents the student's ability to use and recognize language in particular contexts. At this point, in order to refocus the study one must be reminded of the research question posed in the previous chapter: 'what are teachers' perceptions of CLT use in Brazil?' Since Brazil is a foreign language environment, one must review existing literature that relates CLT use in ESL and EFL settings. The following section of this literature review provides a description of both ESL and EFL environments, and presents aspects of CLT implementation in each one.

\section{Differentiating ESL and EFL environments}

ESL occurs in the target language environment (in this case English). This would represent students learning English in the United States, England, Australia or any other country where English is the primary language of interaction, communication, and business. Therefore, students are living and interacting with native speakers, and have overwhelming exposure to the target language (Ellis, 1996). In ESL environments, language learning is not limited to the classroom since students may continue to learn outside the classroom through interactions in their everyday lives. For these students, language learning is more than a curriculum discipline, it's part of survival; they need to learn the language to survive and grow (Ellis, 1996). Another factor is that, in most cases, students in ESL classrooms usually do not share the same native language as their classmates, so creating friendships and interactions in and outside the classroom depends on the learning and development of the target language. In many cases, the culturally 
heterogeneous classroom leads to higher motivation and faster adaptation of learning strategies (Ellis, 1996).

On the other hand, EFL occurs outside the target language environment. It represents students that are learning English in Brazil, Colombia, Mexico, Japan, or any other country where English in not the primary form of interaction and communication among citizens. In this situation, English is part of the school curriculum, or part of extra curricular activities in language institutes. Generally, students in these situations have exposure to the target language only during class time, and cannot test and practice strategies as easily (Deckert, 1987; Ellis, 1996). Frequently foreign language learning is a personal hobby or a school requirement, rather than a survival necessity. Often students learn English with the sole purpose of passing university entrance exams (Burnaby \& Sun, 1989; Gorsuch, 2000; Li, 1998; Liao, 2000). Another factor is that students share the same native language and the temptation to facilitate conversation with the use of the native language at times is irresistible (Liao, 2000; Oliveira, 2002). Students learning in EFL settings may also have various motivations and will not always share the same interest or dedication to language learning (Altan, 1995; Li, 1998).

The environment in which learners experience the language is, thus, extremely important, since it may affect all aspects of the learning process, from motivation to teaching methods used by teachers. Considering that language teaching and learning is greatly affected by the environment in which it occurs, it becomes paramount to describe the existing differences between ESL and EFL as related to the implementation of CLT. A significant factor dealing with environment is the cultural appropriateness of CLT in different EFL contexts. In most regions of the world, learning is done in a 
traditional fashion (i.e., teacher-centered), having very little learner participation in the classroom. CLT requires that students actively participate and this new role for students may cause frustration and even affect their motivation. For example, Deckert (1987) suggests that "many students [in EFL settings] receive the language classroom primarily as an occasion for a teacher's guidance through a textbook or for examination on their own mastery of a textbook" (p. 17). Students feel that the classroom is a place for exposure to "material" in other words, language form. Students that are used to a more traditional teaching style may perceive communicative activities as games. In fact, a study conducted in China stated that students perceived activities common in CLT as games rather than serious learning (Burnaby \& Sun, 1989). However, it's the teacher's responsibility to help students adjust. According to Richards and Rodgers (2001), teachers should assist students in identifying and understanding the value of communicative activities for their communicative competence development. This period of adjustment will help students become more familiar with CLT, and, in consequence, allow them to benefit more from its activities. The activities of CLT for classroom interaction "forgoes much of the familiar and requires something different" (Deckert, 1987, p. 18). Because these activities can lead to student frustration and even rejection of the target language, teachers must guide students through this adjustment period.

According to Kang (1999), "ESL/EFL learners vary not only in terms of their purposes for learning English, but also in terms of individual differences in learning due to their educational, ethnic, and cultural diversities" (p. 9). These differences are extremely important and have been given little attention by authors in the field of language teaching and learning. However, there are some authors that discuss the impact 
of such differences in language learning (Abbot, 1987; Black, 1997; Deckert, 1987; Ellis, 1996; Ellis, 1996; Gorsuch, 2000; White, 1987).

\section{Motivation}

It is said that the most important variable of successful second language learning is motivation. In addition, much of the research indicates that affective and sociocultural factors are key influences for successful second language learners. Such factors include motivation and learner's attitude toward the target language. Motivation as initially conceptualized, is divided into two categories: integrative and instrumental. Integrative motivation deals with the desire to learn the target language for purposes of communication, and interest in the target language culture. Instrumental motivation deals with the desire to learn the target language for practical reasons, such as getting a job or passing an exam. It was believed that successful second language acquisition depends upon integrative motivation, which has been originally defined as the willingness or desire to be like members of the second language community (Gardner, 1968). Later, Gardner (2001) expanded his notion of integrative motivation to characterize integratively motivated students as individuals who are "motivated to learn the second language, [have] a desire or willingness to identify with the other language community, and tend to evaluate the learning situation positively" (p. 9). Integrative motivation seems to be more powerful in maintaining the long-term result that is needed to achieve fluency and proficiency in the target language.

The goals of CLT are to develop learners' communicative competence, dealing mostly with the idea that students want to become proficient speakers of the target language. CLT assumes that the motivation of learners is mostly integrative, thus 
supporting the different communicative activities and styles of teaching. Instrumental motivation, on the other hand, may not lead to real language competency, especially where the goals of learners may be short term, like passing an exam. Indeed, research has shown that in EFL environments learners' motivation is mostly instrumental. A study with Japanese students, which will later be described in detail, concluded that students did not feel a pressing need to use English; therefore, the goal of communicative competence seemed too distant for them (Sano, Takahashi \& Yoneyama, 1984).

In order to help students become proficient in the language, CLT proposes activities dealing with the use of language to carry out meaningful tasks, since "language that is meaningful to the learner supports the learning process" (Richards and Rodgers, 2001, p.161). According to Richards and Rodgers (2001) learning activities are "selected according to how well they engage the learner in meaningful and authentic language use (rather than merely mechanical practice of language patterns)" (p. 161). Taking into account the different motivations that ESL/EFL students have, one may speculate that CLT methodology may not work in both settings the same way. Most scholars agree that second language acquisition research and second language teaching is not directly transferable to foreign language contexts. In ESL instruction, the target language is spoken outside the classroom; the student lives in an acquisition-rich environment and has exposure to the target language in a natural setting. On the other hand, foreign language environment is poor due to the fact that students don't have the same opportunity to interact with native speakers in natural settings. Most of the student's contact with the target language occurs in the classroom, often with teachers who are 
non-native speakers. The following section describes several studies on how CLT is implemented in different EFL environments.

Use of CLT in EFL settings

$\mathrm{Li}$ (1998) conducted a qualitative study of South Korean teachers and their perceived difficulties in using CLT in EFL environments. The study took place in a Canadian university, and surveyed 18 South Korean secondary English teachers, who where at a training program in Canada. All participants answered a written questionnaire, and 10 were also interviewed. Li concluded that teachers' difficulties when attempting to implement CLT were caused by four categories, "those caused (a) by the teacher, (b) by the students, (c) by the educational system, and (d) by CLT itself' (Li, 1998). The four categories where later subdivided into other subcategories.

1. Difficulties Caused by Teachers
a. Deficiency in spoken English
b. Deficiency in strategic and sociolinguistic competence
c. Lack of training in CLT
d. Few opportunities for retraining in CLT
e. Misconceptions about CLT
f. Little time for and expertise in material development

2. Difficulties Caused by Students
a. Low English proficiency
b. Little motivation for communicative competence
c. Resistance to class participation 
3. Difficulties Caused by the Educational System
a. Large classes
b. Grammar-based examinations
c. Insufficient funding
d. Lack of support

4. Difficulties Caused by CLT Itself

a. CLT's inadequate account of EFL teaching

b. Lack of effective and efficient assessment instruments

Li (1998) argues that these numerous problems discourage teachers from trying

CLT. Li also explains that many changes must take place before teachers are prepared to use CLT in EFL environments. "A conflict apparently exists between what CLT demands and what the EFL situation in many countries, such as South Korea, allows. This conflict must be resolved before EFL teaching in these countries can benefit from CLT" (Li, 1998, p. 696). Some of the conflicts that need attention, according to $\mathrm{Li}$, are related to (1) educational values and attitudes, (2) reading, (3) oral skills, (4) grammar, (5) students' attitudes, (6) teachers' attitudes, (7) pre-service teacher education, and (8) local educational growth. Overall, teachers identified more problems than benefits of CLT use in South Korea, thus indicating problems with CLT adaptation in, at least, one EFL environment.

There are important findings in Li's study that relate directly to findings in this present research. Li (1998) reports under the category of difficulties caused by the educational system that teachers perceived class size as an obstacle in implementing CLT. According to Li's findings, "all 18 respondents referred to large classes as one of 
the principal constraints on their attempts to use CLT” (p. 691). In addition, one teacher explained that class size makes it almost impossible to use CLT because of problems with class management, noise, giving individualized attention to students, keeping students on task, and lack of space for teachers and students to move around or get into groups. Another finding in Li's study, under the category of difficulties caused by teachers, refers to teacher's lack of training in CLT. According to Li's findings, "all 18 participants named lack of training as one of the main obstacles they faced in applying CLT" (p. 688). Most of the teachers made comments on the fact that CLT was taught as knowledge and theory, and they had no practical experience in the methodology or its applications.

Finally, still under the category of difficulties caused by teachers, Li's findings state that "fourteen teachers reported that lack of time for and expertise in developing communicative materials had been constraints for them [to use CLT]" (p. 689). As a consequence, teachers gave up using CLT because they were unable to develop materials due to their lack of training in CLT, or because they didn't have enough time to create communicative activities on their own.

Another study conducted by Burnaby and Sun (1989) looked at Chinese teachers use of western language teaching in China. By western language teaching, Burnaby and Sun mean teaching that has as its objective the development of communicative competence among students. The study focused on "teachers' views about using western methods of teaching English as a second or foreign language in their own pedagogical contexts" (Burnaby \& Sun, 1989, p. 220). Data were collected from a Canadian/Chinese cooperative program in English and French language training and cultural orientation in 
Canada, and "an informal study done by Sun on the views on western teaching methods of Chinese teachers at the tertiary level" (Burnaby \& Sun, 1989, p. 224).

The results of this study presented some insight into how western teaching is used and viewed by teachers in China. According to the participants, communicative methods are good for some students, mainly ones that are planning to go abroad, but not good for other students, mainly ones that are English majors. The results showed that teachers see communicative methods as useful for students who will live in English-speaking environments, thus this method is best for ESL environments and not EFL. Burnaby and Sun (1989) divided participants' views into seven categories: Chinese students who would benefit from communicative language teaching, nonnative speakers as communicative language teachers, context of the wider curriculum, traditional teaching methods, class size and schedule, resources and equipment (some of the problems related to a lack of authentic materials and communicative reading exercises), and teachers' professional status. All of these categories seemed to present obstacles for implementing CLT in China. One particular category, class size and schedule, reported in the findings, relates to patterns identified in this present study. According to Burnaby and Sun (1989), teachers viewed class size as an obstacle for using CLT. Teachers in Burnaby and Sun's study indicated that "using communicative methods with large groups was difficult, especially given the pressures to cover the curriculum effectively in the time allowed" ( $p$. 229). In addition, teachers' suggest that CLT does not meet the needs of students in China. Burnaby and Sun (1989) concluded that, even though CLT is widely accepted and appropriate for ESL environments, it may not be the case for all EFL environments, especially China. 
A study conducted by Gorsuch looked at Japanese teachers' approval of communicative activities. Through a 5-point Likert scale, 884 Japanese senior high school EFL teachers answered an extensive questionnaire. The questionnaire was the main source of data for the study; it involved a series of questions on teaching activities. After the analysis of the data collected, Gorsuch concluded that teachers were largely influenced by the requirements of the university entrance exam. The university entrance exam is the most important and competitive exam in the academic career of students, so both the institution and the students put pressure on teachers to let them study materials covered in this exam. Since the exam is concentrated on grammar knowledge, a communicative competence development doesn't meet the needs of students. Gorsuch (2000) also noted that most teachers favored a more traditional way of teaching, and resisted a change to the new teaching environment required by CLT activities. Another factor reported in this study deals with language use. Teachers didn't use the target language in the classroom, and believed students were not ready to use and produce it. In addition, teachers believed that since communicative activities require language use, without explicit directions from teachers, it was inappropriate for English teaching in high schools.

Finally, a study conducted by Altan reported on the culture of English teaching in the EFL environments of Turkey. The study involved 300 Turkish teachers. The data were collected through a questionnaire, which included open-ended questions, direct questions, and items on a Likert scale. Altan (1995) classified teachers' view of English teaching in Turkey into five categories: the teachers' view of the EFL curriculum, teachers' view of language and language teaching, teachers' view of classroom practices, 
teachers' view of their role, and teachers' view of their profession. All the categories were covered in detail in the study, and presented relevant factors such as reasons why students learn English, the aim of the English curriculum, problems with present language teaching in Turkey, and types of activities that benefit students, among others. Altan (1995) also noted that teachers' years of experience also played an important role in the answers to the questionnaire. Teachers with more years of experience viewed that student's aims are mostly to pass examinations. Inexperienced teachers viewed grammatical theories of language as useful in teaching; they also required students to do more reading and writing exercises. Even though teachers differed in opinions because of their years of experience, Altan noted that they shared common ground in many areas, such as "thinking and acting responsibly to help develop their students' learning of English” (p. 21). Altan's (1995) results are extremely useful when comparing them to other projects presented in this study. Most of the topics teachers in Turkey discussed and the problems they faced with English teaching are similar to the ones in the other EFL environments reported in this review.

There have been countless other studies and articles that look into CLT implementation and its problems (Sano, Takahashi \& Yoneyama, 1984; White, 1987; Ellis, 1996; Abbott, 1987; Deckert, 1987; Liao, 2000; Kang, 1999). However, to the best of my knowledge this is the first study conducted that takes into consideration teachers' perception of CLT use in Brazil. There have been other studies that looked into the use of specific aspects of CLT, such as target language use in the classroom (Oliveira, 2002). Other studies attempted to profile Brazilian students (Couto \& Towersey, 1992), and still others considered various aspects of EFL teaching in Brazil (Motta-Roth, Herbele and 
Vasconcelos, 1995). Nevertheless, none of these studies observed specifically how CLT is used. Another unique aspect of this study is its ethnographic techniques, such as class observations and in-depth interviews with participants. The present study goes beyond survey research, which relies mostly on questionnaires, and attempts to report in more detail the aspects of CLT implementation and use in Brazil through the perceptions of teachers. Therefore, this project aims to fill in a gap of existing research in the area of CLT use in EFL environments. It attempts to shed light on the English teaching situation in Brazil. In addition, this study hopes to provide useful information to teachers and educational institutions that deal with foreign language teaching. 


\section{Chapter 3}

\section{Research Design}

Communicative Language Teaching (CLT) is a popular teaching approach and has been recommended in many schools and institutions. Traditionally, this approach focuses on developing the communicative competence of students. Communicative competence, according to Savignon (1972) refers to the "ability to function in a truly communicative setting" (p. 8). Although CLT is widely known, little is mentioned in the literature about the application of this approach in different educational environments. This study aimed to discover teacher perceptions of CLT in EFL classrooms in Brazil. In view of the requirements that CLT places on learners as well as teachers, there is much to be asked about the ability to adapt this approach to EFL settings. The primary focus of this study was on teachers and how they played a part in the adaptation and use of CLT in EFL environments. This study asked one research question: what are teachers' perceptions of CLT use in Brazil?

The research relied mostly on teachers' feelings and experiences about the use of CLT in Brazilian classrooms. Thus, a qualitative research design was chosen because the study deals with personal perspectives and experiences. Qualitative research is recommended for studies concerned with complex phenomenon. Furthermore, reasons for selecting qualitative research are "to stress the unique strengths of the genre for research that is exploratory or descriptive, that assumes the value of context and setting, and that searches for a deeper understanding of the participants' lived experiences of the phenomenon" (Marshall \& Rossman, 1999, p. 60). More importantly, qualitative research is characterized by its lengthy involvement with participants, through 
observations and in-depth interviews. In addition, this research methodology takes into account the influences of context and setting on participants' perceptions, which is central to the research question of this present study.

Qualitative research has been well established in most academic fields of study. It has a unique approach to research that draws mostly on multiple sources and on people's views and opinions of specific experiences. In this specific study, it was important to use a qualitative research approach due to the reliance on individual perceptions of a particular situation. "Qualitative researchers are intrigued with the complexity of social interactions as expressed in daily life and with the meanings the participants themselves attribute to these interactions" (Marshall \& Rossman, 1999, p. 2). Not only was it important to document teacher's perceptions, but also to determine how their environment, in this case an EFL environment, affected and shaped such perceptions. Since, as mentioned previously, the context and setting in which teachers experience the phenomenon affects their overall perceptions.

The use of triangulation to validate data is an important aspect of qualitative research and serves to guarantee credibility in reporting findings. Triangulation has been define as "the collection and comparison of data from two or more separate observations or illustrations of the behaviors being studied" (Amores, 1997, p. 521). This was a significant tool used in this research to gather data. Data were gathered through questionnaires given to participants, observations of classroom activities and procedures, and interviews with participants that helped validate both the answers in the questionnaires and observations. 


\section{Setting}

Data were collected for this research from four different schools in a large city in Southern Brazil, Satopel, each with different settings and characteristics. The first school was a public high school, Antonio Martins. ${ }^{1}$ This school is run by the state and receives state and federal funding. The school is located in the city downtown area. It is a large corner building with three floors and was originally built to be a school. It has large classrooms on the second and third floors. The first floor has mostly administrative offices and a teachers' room. The school has an open patio area in the center. There are large windows in each classroom facing both the inside patio and the street. Some of the street windows were broken, and most of the building has graffiti over the chipped paint. In the hallways one can observe students running around, doors slamming shut, and the loud bell that marks the beginning and end of classes. The staff was extremely friendly and helpful, answering students' questions, smiling, and even directing strangers through the building. The classrooms are large, but the number of students averaged about 45 per class, leaving almost no empty seats.

The second school was a private Catholic high school, Santa Marta, located beside the large private Catholic university in town. This school was originally built as a nun's convent. The building extends a whole block. The grounds have an open patio, an inside recreation center, a small chapel, and the main building with administration offices and classrooms. Inside the hallways are pictures of past teachers and school directors, and plates with awards and religious messages. The main floor has the teachers' room and administrative offices while the other floors have classrooms. There were no nuns

\footnotetext{
${ }^{1}$ Names of people, places, and institutions have been changed to maintain anonymity.
} 
walking around, mostly just regular teachers and uniformed students. There was an average of fifty students per class and literally no space between desks.

The third school was a franchised private language institute, Yellow. The school has two locations. One campus is across the street from the first school mentioned, and the second one is downtown on the other side of the Catholic University mentioned above. The two locations have visible computer rooms, teacher rooms, and small classrooms. There are an average of 7-10 students in each class. The walls are filled with school events and special promotions posters.

The fourth and final school is a small non-franchised private language institute, Ultramar. The school has two stories and had a large welcome flag over the front door. The walls are filled with mostly United States artifacts, with specific translations. The artifacts included motivational posters, money, political figures, and maps. Most of the regular school equipment, such as telephones, stereos, desks, chairs, and computers, have little notes with their English names. The classrooms are small but also filled with authentic artifacts and English translations. There were about 7-10 students in each language institute class.

Class time ranged from fifty minutes in the high schools to ninety minutes in both of the language institutes, with the exception of one class observed, at Yellow, that ran three hours. Most classes met twice a week, with the exception of the three-hour class that met once a week. A total of 45 hours of class observation time was conducted during this study. In the regular curriculum classes, there were a large number of students per class. Most classrooms were set up in rows of chairs and desks, with a large blackboard at the front of the class behind the teacher's desk. Students had little room to move 
around in the classroom, and teachers stood at the front of the class for the entire duration of the class. In both of the language institute classrooms, chairs where arranged in a circle skirting the wall of the room. The teacher's desk was very small, and most of the time teachers sat among students or walked around the classroom's open space. There was a large white erase board on the wall and other equipment, such as stereos and televisions in some of the rooms.

\section{Participants}

A total of seven teachers participated in the study. The seven participants were from the four schools mentioned above. Two female teachers came from the high schools, Angela from Antonio Martins, and Rita from Santa Marta. The remaining teachers came from the private language institutes, Marta, and Fernando from Ultramar, and Anita, Vinicius and Roberto from Yellow. Tables 1, on page 32, and Table 2, on page 33 provide demographic data of participants. 
Table 1

Participant Demographic Data

\begin{tabular}{lllcl}
\hline Participants & Gender & Age & Years of Experience & School \\
\hline Angela & Female & over 32 & 9 & Antonio Martins \\
Rita & Female & over 32 & 16 & Santa Marta \\
Fernando & Male & $18-24$ & - & Ultramar \\
Marta & Female & over 32 & 10 & Ultramar \\
Vinicius & Male & over 32 & 15 & Yellow \\
Roberto & Male & $25-32$ & 9 & Yellow \\
Anita & Female & $25-32$ & 11 & Yellow \\
\hline
\end{tabular}


Table 2

Participant Training Background

\begin{tabular}{|c|c|c|c|c|c|c|}
\hline Participants & B.A. & M.A. & $\mathrm{TC}$ & EWS & IEPA & LA \\
\hline Marta & Liberal Arts & & $\mathrm{X}$ & $\mathrm{X}$ & $\mathrm{X}$ & $\mathrm{X}$ \\
\hline Fernando & - & & $\mathrm{X}$ & & & $X$ \\
\hline Vinicius & Linguistics & & $X$ & $\mathrm{X}$ & $\mathrm{X}$ & \\
\hline Anita & Linguistics & & $\mathrm{X}$ & $\mathrm{X}$ & $\mathrm{X}$ & \\
\hline Roberto & Linguistics & & & & & \\
\hline Angela & Linguistics & & $\mathrm{X}$ & & & \\
\hline Rita & Linguistics & $\mathrm{X}$ & $\mathrm{X}$ & $\mathrm{X}$ & & $\mathrm{X}$ \\
\hline \multicolumn{7}{|c|}{ TC - Training Courses } \\
\hline \multicolumn{7}{|c|}{ EWS - English Workshops } \\
\hline \multicolumn{7}{|c|}{ IEPA - Intensive English Program Abroad } \\
\hline
\end{tabular}




\section{Angela}

Angela is a well-dressed and soft-spoken woman. She has been an English teacher in public high schools for nine years. Her educational background includes a B.A. in linguistics and special training courses throughout her teaching career. She teaches mostly young adults, ages 16-25. Class sizes range from 40-45 students per class, and she has six or more classes to teach each semester. Angela indicated that she spends 5-10 hours a week preparing classes, and that most of the material used for classes come from the school library, magazines, the Internet, and training workshops and seminars. She also indicated that most of the activities done in class are focused on reading, since she believes that is what her students need. "I prefer work with reading techniques because I think it's what Brazilian students or Satolepenses [from the city of Satolep] will need in the future." Observations of her classes confirmed in part Angela's statement, and, certainly, none of her lessons included communicative activities that provided students with opportunities to exchange real information. During the interviews and outside the classroom she communicated mostly in Portuguese, her native language, and found it difficult to understand the English questions posed to her. In the classroom she communicated with students mostly in Portuguese as well and used English only to give answers to exercises. She used Portuguese to explain exercises and assignments to students.

Rita

Rita has lived in the United States and has extensive experience teaching English. She enjoyed sharing ideas and spoke English as much as possible. Rita has been an English teacher in private English schools and private high schools for about sixteen years. Her 
education includes a B.A. and Master's degree in linguistics, training courses and English workshops, and some academic experience at a university in New Jersey in the United States. Rita teaches youngsters ages 11-15, and class sizes range from 35-45 students per class. She teaches six or more classes per semester and spends about 10-15 hours a week preparing for classes. She also indicated that most of the material she uses in the class comes from friends, magazines, newspapers, the Internet, a personal library, and seminars she attends. She also stated that CLT was difficult to implement due to the number of students in her classes and because of the students' behavior and special needs: “...the school prepares students for the 'vestibular' (university entrance test) which, in turn, requires reading proficiency." She further added that "Sincerament eu não ensino inglês, ensino leitura." [Honestly I don't teach English, I teach reading]. Although she elected to conduct her interview in Portuguese, most of the casual conversations were in English. During class she spent most of the time communicating with students in Portuguese due largely to students' questionable attitudes. The high school classes where extremely noisy, and unruly, so the teacher spent time lecturing and trying to control student behavior. Rita appeared comfortable speaking English, even though she didn't speak English during her classes.

\section{Fernando}

Fernando is a young man, dressed casually in jeans and a T-shirt, always late for classes and always with a cup of coffee in his hand. He was very friendly and seemed comfortable speaking in English. Most of the conversations conducted with him were in English, and he always seemed to think a lot about his answers. Perhaps because of his double role of both teacher and student, Fernando gave the impression of being tired, 
since most of the time he appeared to have just woken up. Fernando is currently working on his B.A. in linguistics; he has taken training courses and has lived in the United States. He has taught English in Richmond, Virginia, and is currently teaching at private English schools and college preparatory schools. He teaches all age groups, from children to adults, and has an average of 10-15 students per class. He has six or more classes each semester and indicated that it takes him less than five hours a week to prepare for classes. Most of the material he uses comes from the school and his personal library, friends, magazines, the Internet, newspapers, and training workshops, conferences, and seminars he attends. Fernando seemed to know about CLT even though he indicated that he uses other teaching approaches in his class: "I think it is a great way of teaching [CLT], though not most appropriate to be used alone in Satopel."

\section{Marta}

Marta is professionally dressed, and extremely polite. She always made it a point to speak English to me during our conversations. She has been teaching English in private English schools for over ten years. She is also the director of the school. Her academic background includes a B.A. in Liberal Arts, training courses, and English workshops, and she has lived in the United States. She teaches all age groups and has an average of fewer than 10 students per class. Marta usually teaches six or more classes each semester and spends 5-10 hours a week preparing for classes. Most of the material she uses in class comes from friends, magazines, a personal and a school library, the Internet, seminars she attends, and from a daughter who lives in the United States. Even though she indicated that she didn't "know how to work with this method [CLT] of teaching," her classes proved different. She seemed to have a close relationship with her students, 
always asking them questions in English outside of the classroom. Marta always had a smile on her face and seemed very comfortable speaking English. All conversations with her were conducted in English, and she made sure her students always heard her speak English to the other teachers in the school. Marta had a way of creating fun situations for her students, and they seemed to be relaxed speaking English around her.

\section{Vinicius}

Vinicius is a middle-aged man, who dresses informally in jeans and T-shirts, and usually walks with his hands in his pocket. He has a relaxed posture and likes to walk around during class time. He has a distant look, as if he is always in deep thought. He smiles at times and seems to feel comfortable in the classroom with students. Vinicius has been teaching English in private English schools and college preparatory schools for about fifteen years. His academic background includes a B.A. in Linguistics, training courses, Intensive English Program study abroad, and English workshops. Vinicius teaches mostly young adults, ages 16-25, and adults 26-35. He has an average of 10-15 students per class, and usually teaches 10 classes each semester. In addition, he has four tutees, and spends about 5-10 hours a week preparing for classes. Most of the materials used in his class comes from a variety of sources, including trips abroad. Vinicus finds CLT approach to teaching to be useful, "in my opinion this is one of the most efficient methods." He seems comfortable speaking English and had no problem during casual conversations and during the interview.

\section{Roberto}

Roberto is a young man, who is well dressed and very polite. He has been teaching at private English schools for about nine years. He has a B.A. in Linguistics and is working 
on getting his MA in the same major. Roberto teaches mostly young adults ages 16-25, and adults 26 and older. He has an average of 10-15 students per class and about four classes each semester. He spends 10-15 hours a week preparing for classes, and most of the material he uses comes from magazines, conferences, newspapers and the Internet. Roberto found CLT a useful methodology: "I believe CLT is a good approach to language teaching, no matter the environment it is used. What counts when it comes to teaching is what teachers do with CLT." He seemed comfortable speaking in English and was extremely interested in the research project. He appeared happy to participate and asked many questions about the research. Roberto spoke English with his students in class and outside of class in the halls of the school.

Anita

Anita seemed to be a busy person, always rushing from one room to another. She was professionally dressed, with makeup and red-hot lipstick. She was always cheerful, smiling, and ready to help, a very sweet and polite person. Anita has been teaching in private English schools for about 11 years. Her background includes a B.A. in Linguistics, training courses, Intensive English Program study abroad, and English workshops. She teaches all ages of students and has an average of 10-15 students per class. She is the coordinator at the school, so she only teaches two classes each semester. She spends less than five hours a week preparing for classes, and most of the material she uses comes from school and personal libraries, magazines, the Internet, and seminars she attends. Anita seems to understand the theories involved in CLT, however she states, “our country's [Brazil] educational system doesn't provide too much space for critical thinking, independence, and autonomy. In my opinion, these aspects are fundamental if 
we are willing to work with CLT, thus our work becomes even harder." She seemed interested in the research, and was well prepared to answer theoretical questions about CLT. She seemed comfortable speaking English during casual conversations and during the interview. She spoke mostly in English in class, but outside the classroom she spoke Portuguese with the students.

\section{Procedures}

The first stage of the study was contacting the schools in Brazil, where the research was going to take place, for authorization; a total of five schools were contacted and four responded positively. The researcher first met prospective participants during informal meetings at each school. The study was explained to all the participants and they were asked to respond to the questionnaire. It was made clear during these initial meetings that participation would be voluntary, and no benefits would be given to selected participants. At this time, prospective participants were also given the opportunity to ask questions about the research. After collecting the questionnaires, the researcher selected seven participants. Each participant was then contacted individually through the school to arrange for class observation times.

During the second stage of the study the researcher entered each participant's classroom. Observations lasted about four weeks, and then the researcher reviewed notes taken from the observations to formulate additional questions for the post-observation interviews. The final stage of the study involving the participants was the interviews. Interviews were scheduled with each participant individually after the last observation class. Interviews were conducted informally, and participants spoke about various teaching experiences, specific observed situations, and materials used during classes. 
Participants were also asked for their contact information during interviews, in the event that follow-up was necessary.

\section{Questionnaires}

The purpose of the questionnaire (Appendix A) was to first select the participants for the study. The questionnaire was designed to give the researcher background information about the participants as well as their general perceptions of the CLT approach. The questionnaire had direct questions about age, academic backgrounds, and teaching situations. Open-ended questions were also included in the questionnaire, which served to judge participants understanding of CLT, English teaching in general, and language proficiency in English. A total of 14 teachers were given questionnaires and then seven were chosen to participate in the study. In the selection process it was important for the researcher to identify participants that had some knowledge or experience with CLT. Therefore teachers that responded clearly and concisely about CLT and gave relevant responses to open-ended questions were given preference. Since the primary focus of the study is on CLT use in Brazilian classrooms, participants that showed more knowledge on the topic were selected. This helped secure usable data for the study. All questionnaires were written and answered in English. With the exception of one teacher, none seemed to have problems understanding the questions and answering them. Another purpose for distributing the questionnaire to various prospective participants was that the researcher hoped to understand more about the training background of teachers, and their language teaching experiences in different methods, factors that would inevitably affect their perceptions of CLT and the environment in which they taught. 


\section{Observations}

After teachers were selected based on their responses to the questionnaire, observations in the classroom began. A total of four weeks of observations were conducted in May - June 2002, with an average of 10 hours in class observation per teacher. Observations were essential to the data gathering process, providing a source of documentation of activities, behaviors, and teacher-student interaction. Observations also served as a way to confirm responses from questionnaires with the actual events of the classroom. Observations consisted of extensive note taking of student, and mostly, of teacher behavior, since "through observation, the researcher documents and describes complex actions and interactions," (Marshall \& Rossman, 1999, p. 107) that occur in the classroom. Since the researcher had previously done extensive reading about the CLT approach and had experienced it in the classroom in other occasions, a checklist was created to identify specific CLT behavior. The use of a checklist (Appendix B) served to focus the observation of CLT characteristics and organize the data observed. The checklist was used together with note taking of classroom interactions and behaviors. Observations also helped to "discover the recurring patterns of behavior and relationships," (Marshall \& Rossman, 1999, p. 107) and provided a source for the formulation of additional questions for the interviews.

\section{Interviews}

Only the participants selected for the study were interviewed. All interviews lasted between 60 and 120 minutes and were conducted in each participant's school. The main purpose of the interviews was to provide the researcher with an in-depth understanding of teaching perceptions of CLT use in EFL environments. Interviews also 
served as a way to triangulate the data during observations. A list of eleven open-ended questions (Appendix C) was prepared for the interview. Participants reviewed questions briefly before the interview was conducted. Additional questions were added according to specific in-class observations of each participant. Marshall and Rossman (1999) state that, "typically, qualitative in-depth interviews are much more like conversations than formal events with predetermined response categories" (p. 108). Therefore, most of the interviews were very relaxed, and felt more like conversations. Participants felt free to speak their minds and add additional information to specific questions. Participants were also free to use their native language in case they felt 'out of words' in English. Most of the questions focused on teachers perceptions of their experiences using CLT, or not, in EFL environments. A few questions related more to the EFL environment and how teachers felt with their teaching experiences. The interviews were also a way to gather large quantities of data and identify similarities between participants' situations. In order to gather accurate information, all interviews were taped with participants' approval and later transcribed by the researcher.

\section{Data Analysis}

To analyze the data of this study, the researcher spent many hours reading all the material gathered, including questionnaires, observations, and interviews. The "immersion strategies which do not prefigure categories and which rely heavily on the researcher's intuitive and interpretive capacities,” (Marshall \& Rossman, 1999, p. 151) serve to organize information. As reading occurred, patterns were identified, and were divided into main categories. The patterns identified by the researcher indicated that the teachers from the various schools experienced similar problems when attempting to 
implement CLT. This consistency in the findings, presented in the next chapter, helped answer the research question. 


\section{Chapter 4}

\section{Findings}

\section{Introduction}

I know that they [universities] motivate students and future professionals to use communicative approaches, what happens is that some students I would say $40 \%$, I hope I am not exaggerating, but $40 \%$ if not $50 \%$ of the teachers don't know exactly what the communicative approach is... I have a lot of training because I am in a private school, I am a privileged one, you know. Because, for instance, state and city teachers they really don't have training, they never have training. When they have it, it's theory, they see theory, and when they go to class they don't know how to apply all those theories, because the lectures and the workshops they attend are not well structured to get them to know exactly what to do or how to proceed in class in a practical way, they consume most of their time involved with theory. If you talk to teachers they know authors, they know theories, they know definitions, but when it comes to class, if you visit their classes, you see that they don't really work in a communicative way.

Vinicius' previous remarks suggest what was perceived through data analysis, that teachers' awareness of CLT may be a cause for ineffective CLT implementation. As a result, teachers were unable to implement such principles in their classrooms.

According to Richards and Rodgers (2001), CLT is an approach to teaching that reflects a communicative view of language. Some of the principles of CLT include.

- Learners learn a language through using it to communicate. 
- Authentic and meaningful communication should be the goal of classroom activities.

- Fluency is an important dimension of communication [exchange of ideas or information between two or more people].

- Communication involves the integration of different language skills.

- Learning is a process of creative construction and involves trial and error. (Richards \& Rodgers, 2001, p. 172)

In order to properly implement these principles in the classroom, teachers must design their syllabi based on the promotion of communicative competence. According to Prabhu (1983), the "only form of syllabus which is compatible with and can support communicational teaching seems to be a purely procedural one - which lists, in more or less detail, the types of tasks to be attempted in the classroom and suggests an order of complexity for tasks of the same kind" (p. 4). The notion of a communicative syllabus, and, in consequence, the implementation of the principles listed above has been subject to debate (Littlewood, 1981; Lee \& VanPatten, 1995; Prabhu, 1983; Richards \& Rodgers, 2001; Savignon, 2001). Most researchers agree that a communicative syllabus includes, in some aspect, task-based lessons, in which students are expected to perform meaningful tasks through communicative interactions. At least one example of such a lesson was observed in Marta's class.

Marta gave a class, in which, she created an environment for students to learn 'party' vocabulary, and students really got into the activity. They took on characters without the teacher's instruction, and started using vocabulary they had learned from other sources, such as movies and music. They said things like, "I really like your shirt? 
Thank you. Where did you get that? At Krauz. Do you want something to drink? The music is so loud in here! Do you want to dance? Sure, lets dance. Look at our teacher; she is dancing!" As the activity progressed the teacher kept introducing new vocabulary, and students would ask 'what does that mean?' The classroom was filled with party decorations, a table was set with drinks (Coke) and food, and the music was loud. The students really felt like they were in a party, they smiled and walked around talking to each other, all in the target language. At the end of the class students walked out making comments, such as "that party was cool." Cool being one of the vocabulary words introduced during the class.

The data reveals that teachers participating in the study, with the exception of Marta, did not use CLT activities in their classrooms. Angela and Rita relied more on grammar and reading activities, which were not communicative but rather lectures of explicit grammar rules. Vinicius, Roberto, and Anita relied exclusively on the book. In class, all the activities were individual and group work on book exercises. As Roberto himself recognized during his interview:

I have colleagues and, if you ask them the approach they use, all of them will say communicative approach, but by the examples they give they don't use it and I myself don't use it...People deny other methods and praise CLT so much, but they don't even know what they are doing.

The following pages echo Roberto's remark, that teachers are unfamiliar with a communicative teaching methodology and, therefore, are unable to implement its principles in the classroom. 


\section{Teachers' awareness of CLT principles}

It's about 6:05 P.M. and Vinicius and I are walking through the hallways to get to class. We are a few minutes late. Vinicius smiles as he enters the class excusing his delay. Students are already in their seats. Vinicius explains, in the target language, that they will work on cause and effect structures. Each student is given a slip of paper with a word. Students are told to create a hypothesis with a restriction. Vinicius adds that they should use contrast linking words to add restrictions to their sentences. At 6:17 P.M. a student arrives late, the teacher walks over and explains the activity in Portuguese. Vinicius walks around the room assisting students with their work. Some students speak Portuguese. However, mostly they work individually on the exercises, without interaction. As students complete the exercise they begin to interact with each other. Students talk about topics unrelated to the class activity. Some students look around the classroom with a distant look. After everyone is finished, students take turns reading answers aloud to the group. One student gets the model incorrect, the teacher immediately corrects him and gives a suggestion on how to use the model provided for the activity. At 6:40 P.M. the teacher directs students to work on another exercise in the book, he reads the directions of the exercise aloud to the group. Students have no interaction with each other, they don't have eye contact, and they are always looking down at their books and completing exercises. Students are called on to give answers to the exercises, teachers provides correct answers, or confirmation of such. Another exercise is assigned from the book, this time 
students are told to work in pairs. The teacher walks around the room providing assistance, or sits at the front of the class. Students give answers to the exercise aloud. The teacher provides feedback, and grammar corrections to sentence structures given by students. Teacher gives a brief explanation of a grammar rule that applies to the student error. 7:05 P.M. students are asked to open their other textbook and turn to page 35 . They are directed to work individually on exercise 6 , working with conditionals and 'if clauses.'

Students begin to work. At 7:15 P.M. class is over.

The lesson described above is representative of most of the classes observed, consisting of individual and group grammar exercises from the book. Students were guided by the teacher to work on exercises together, and then the teacher and students would go over the correct answers. The textbooks, and at times listening exercises from the book, were filled with artificial language and mechanical work. At Antonio Martins, one of the high schools, the classes observed consisted mostly of silent reading activities, reading comprehension exercises done individually or in groups, and showing of American films with Portuguese subtitles. In the other high school, Santa Marta, classes consisted mostly of explicit grammar instruction. The teacher would write sentences on the board, and ask students about grammar rules, and share her own knowledge of their correct use. None of these classes presented any communicative activities, or opportunities for students to use language in simulated real life situations.

Most of the teachers seemed to be familiar with CLT principles. For example, in the questionnaire Fernando defined CLT as a way to "get students 
involved in real use of the language context. Having students solve language problems by their own as if they were in an English speaking environment, focusing on eloquence rather than grammar accuracy." Anita on her part, defined CLT as having "a lot to do with interaction. It uses communication as a means to reach the goal, which is also communication. Teachers' and students' role vary all the time. The process of mediation is a way to achieve good results." However, observation of their teaching practices revealed that teachers might not be aware of how to implement CLT principles in their classrooms, even though they claimed to do so.

According to Gomes de Matos and Pinto (2000) few teachers in Brazil have the opportunity for graduate studies in foreign language teaching. They also added that most teachers rely on seminars and workshops for professional training. In many ways, as Vinicius himself recognized in the previous statement, these training workshops and seminars present mostly theory and fail to train teachers properly to implement, in practice, such theories in the classroom. This finding concurs with Li's (1998) study in South Korea. Li reports that teachers there "named lack of training as one of the main obstacles they faced in applying CLT" (p. 688). Teachers in Li's study also added that "they had learned about CLT in different ways - in university methods courses, English teaching conferences, and English teaching journals - but they all agreed that they had not practiced it much" (Li 1998, p. 688).

Vinicius' remarks at the opening of this chapter support these research findings when he states that teachers "know theories, they know definitions, but when it comes to class...they don't really work in a communicative way." Other participants agreed with Vinicius in this respect. For example, Fernando explained that his "colleagues, English 
teacher classmates get lost trying to use CLT. Sometimes they just ask the students to go on the Internet and search all they can about a subject, and they think it's learning. You know, teachers get lost trying to apply CLT in the classroom. I think they know the methodology of CLT well, but I think that it's difficult for teachers to prepare. Teachers try to do something, like use a technique of CLT, but they don't understand how." The data collected shows that most teachers participating in the study have a basic understanding of CLT in theory, but have a hard time adapting it in practice in the classroom. Even Vinicius, who considered himself "privileged" because he worked in a private school and had "a lot of training," and who claimed that, "it's from/through the negotiation of information that students learn how to acquire or learn a foreign language," showed few CLT activities in his class.

In addition, some teachers assumed that CLT would only function for beginning level students. For example, Rita stated during her interview that:

Some students are placed in private English schools by their parents since they are very young children. So if we are to initiate the communicative approach in high school, and for these students it will become boring. They don't want that anymore, they have the need for a more advanced level and we can't do that in schools. I mean we can make that difference in schools. So I would say that for the schools and the way schools do things, everyone has to see the same material, it's not viable to use CLT. I think something would have to be readapted.

Rita assumes that CLT activities cannot be adapted and presented for advanced level students. Her perception of role-play activities, and simulations, which represent the 
communicative principles of CLT, is connected to 'childish games' and she perceived students would find it 'boring' in advanced classes.

This perception was also observed in Anita's class. All class observations were done in advanced groups, with exception of one beginning level class of Anita's. This class was formed of nine students. During the class, Anita performed some game-like activities with the students. There were two vocabulary games. The first consisted of an act out game, in which students were asked to stand in the center of the class and act out one of the words they had learned in the previous class. The student that guessed the word correctly would then go to the center of the room and mimic another word. The students seemed to enjoy the activity, they laughed and gave each other feedback in the target language. The second activity consisted of placing vocabulary into sentences. Each student was given a slip of paper with a sentence. The teacher then directed students to go around the class and find their pair, another sentence that matched the one they had. Students worked simultaneously on the activity, going around the room asking each other questions until they found their appropriate pair. After each student had their pair, the teacher directed them to open their books and work on the exercises of asking and answering questions.

These activities in Anita's class appeared communicative in nature, and gave opportunities for students to use the target language spontaneously. However, this was a beginner class, and when asked during the interview about this situation Anita replied, "they are children so they like to play games. It's fun for them, and they learn that way." It appears that Anita, much like Rita, assumes that communicative activities are for beginners, and that they are games, which 
advanced groups, would not enjoy or need. Indeed, none of the advanced classes taught by Anita contained any communicative activities similar to the ones in the beginning level class. Most of the advanced classes were focused on book exercises, which were mostly mechanical and artificial language practice. Quite a different picture was found in Marta's class. Regardless of student proficiency level, her classes always employed actual environment transformation according to themes she was working on with students, thus providing them with the opportunity to experience the target language in real-life situations, as shown below.

Marta gave a class on the topic of New York City. During this class Marta brought in maps, postcards (blank and written), artifacts, souvenirs, and music. She began by having students brainstorm what they would expect to find in New York. After a short discussion Marta introduced the materials she brought to class. Students where able to see, touch, feel, comment on and discuss artifacts. The class was upbeat, and filled with new vocabulary. Students questioned the instructor about the material, and shared their own experiences about New York. Even though none of the students had actually been to New York, some had received postcards, or knew people that had traveled there. Others reported on travel to other important cities of the world. Towards the end, the teacher introduced a song about New York. Students learned the lyrics and sang together. Finally the teacher introduced the chapter in the book that spoke about traveling to New York.

At Ultramar many similar classes took place, all of which appeared to produce a high level of student interest throughout the activities. Marta remarked: 
I think students like much more this kind of teaching, I have seen that every time I prepared a class like that, after some time two or three weeks they come up and tell me 'I liked that class very much I never forgot how to say that.' They make a lot of comments about those classes, I definitely believe that it's easier for students to get fluency with the language.

A key element of CLT is communicative activities, involving the use of authentic materials, role-play, sharing goals and objectives of activities with students, presenting materials that relate to students' reality. These components provide a comfortable atmosphere for acquisition to take place. According to Richards and Rodgers (2001) the use of authentic materials is essential in CLT. They help students develop more authentic communicative interactions. They state:

Many proponents of Communicative Language Teaching have advocated the use of "authentic," "from-life" materials in the classroom. These might include language-based realia, such as signs, magazines, advertisements, and newspapers, or graphic and visual sources around which communicative activities can be built, such as maps, pictures, symbols, graphs, and charts. Different kinds of objects can be used to support communicative exercises, such as a plastic model to assemble from directions (Richards \& Rodgers, 2001, p. 170).

There has been extensive research on the use of authentic materials in communicative activities. Most researchers agree that a unique and positive characteristic of CLT is in fact the use of authentic materials (Dubin, 1995; Larsen-Freeman, 1986; Long \& Crookers, 1992; Nunan, 1991; Reid, 1995; Widdowson, 1996). Marta agrees, and 
perceives authentic materials as essential for her students' learning process. According to Marta:

For most students the classroom is the only place they have the opportunity to see real things, and that they are able to learn English in a natural way, and not in an artificial way. I bring something to my class made in the US, and they are so much happier to see it, they love to see real things, it's not the same if you have artificial materials. Once I brought to my class a baseball, when we talked about sports, and students love that, even the material. They say things like, "Oh I can't believe that, is it really like that," it's different if you see the size and can touch things, through a picture or on a book. It's not the same as if you touch the ball, and the real size and feel of it. So it makes the student have an idea of how heavy it is, how soft it is, so that kind of thing of working with senses is in my opinion one of the most important things in class. I have seen that all my students learn much faster whenever they can touch, smell, see and hear, rather then just reading from books.

One thing that was really apparent during Marta's observations was her ability to transform the environment for the students. She decorated rooms, filled them with authentic artifacts, and at times students appeared to be inside a room rather than a classroom. Marta explained that the classroom can at times be an obstacle for learning, changing that regular environment for students can motivate them to learn and get excited about learning. She added that it is possible to transform the classroom, all teachers need is to be more dedicated and take more time preparing class. 
I think it's possible to create an environment where you can use real things, and where students can feel open to communicate using real things. They can take advantage of being in that altered place, it's like being in an unusual place other than the classroom, where they are used to go, and were it's the same setting with chairs, and tables.

Marta also stated that students get excited about being in contact with real materials, and it helps them experience rather than just learn.

"My experience working with students with real materials is that students get so excited about touching things that came from the US, they are always comparing things, 'oh I never thought they had that, oh how nice' they like touching real things, even though sometimes I just use some postcards and it's something that makes them feel that in some way they are touching something that is real, that comes from a native speaking country, so they get much more excited about those materials, and I think the conversation flows better, and they are usually more talkative in class, when they get in the classroom and the environment is different and I have new things for them to see."

According to Marta this allows students to experience language, and creates an atmosphere of enjoyment and fun.

Most of the teachers, however, failed to create this authentic setting for students, and, in addition, failed to recognize the resources available to them. As Vinicius remarked during his interview: 
Sometimes one of the things that is very clear for me is when one student doesn't have conditions to learn or to achieve what he is supposed to in a communicative approach. The background knowledge of the student is sometimes poor. The student really doesn't have any contact with the English language, you know, they listen to certanejo [Brazilian country music], they listens to samba [Brazilian folk music], English is not present in their world, that's the point. On the other hand, sometimes when you talk to students who have good conditions and access, for instance, those students from private high schools their background knowledge is completely different because they have computers at home, they have DVDs, they have all those machines so they must know English or have an idea. Their parents have studied English before, so background knowledge is very important ...things for instance that I always tell colleagues "what is the use of talking about atomic bomb to a student that doesn't know what a match is." If he doesn't know or has never lived one similar experience, there is no use talking about, because he will forget soon, and he is not going to find any use for this. So we have to find one link to the content or whatever and the student's life, for this to make sense, because in our case, for instance, when they leave the classroom they almost practically leave the language.

Although most participants agreed that students have little exposure to the target language outside the classroom, I observed a different reality around the city and in the classroom. During my time around the city I observed many influences of the target language. T-shirts with English slang vocabulary and sentences; English music playing 
on the radio constantly, American films playing at local theaters; American and British channels on local TV with no subtitles; imported stores with all American products with labels all in English; computers with English versions of programs. In fact, on various occasions students talked about experiences with English outside the classroom, during their classes. In one of Anita's classes students talked about American movies they had watched over the weekend, and asked about vocabulary they encountered. Some students had watched the film Spiderman. Students also asked about cultural aspects of the target language that they observed in movies. I also observed, in Fernando's class, students talking about vocabulary words they heard in songs played on the radio.

All the English input students received were not taken advantage of by most teachers participating in the study. In fact, it was only at Ultramar, that the teachers appeared to incorporate this outside exposure of the target language into the classroom. For example, a homework assignment in which students were required to list vocabulary they hear during films, TV shows and music for one week was typical in Marta's class. Students were asked to list the vocabulary that was known or unknown to them, with the source of each word. Students had various words in their list, an indication that even if limited, English language exposure did exist outside the classroom. This assignment seemed to help students incorporate outside exposure with learning strategies they gained in class.

In addition, during the interview, Fernando gave some examples of how he incorporates outside English exposure with activities in the classroom. He states:

"In many occasions I have used things outside the classroom. I think that should always be used, especially music. Usually, I ask my students to do 
some jobs, some works, like watching movies and writing some words, or having some songs and writing something about their lives, or just listening to the song and tell what they felt. Sometimes I ask them to bring something they saw in English on the streets, we can use everything."

Integrating a wide variety of sources of the target language is essential for communicative competence development. According to Canale (1983) the "primary objective of a communication-oriented second language programme must be to provide the learners with the information, practice and much of the experience needed to meet their communication needs in the second language" (p. 19). The use of English exposure outside the class, provides opportunities for in-class activities, that in turn validate students' learning strategies and facilitate learning. However, as stated before, most teachers in this study chose not to incorporate authentic materials in their classrooms, although in their responses to the questionnaires they maintain that they have easy access to it. Table 3 shows teachers' responses to the questionnaire when asked where they retrieve authentic materials to use in their classes. 
Table 3

Sources of authentic materials from the target language

\begin{tabular}{|c|c|c|c|c|c|c|c|}
\hline & Anita & Roberto & Fernando & Marta & Vinicius & Angela & Rita \\
\hline School Library & $X$ & & $X$ & & $X$ & $X$ & \\
\hline Friends & & & $X$ & $X$ & $X$ & & $\mathrm{X}$ \\
\hline Magazines & $X$ & $X$ & $X$ & $X$ & $X$ & $X$ & $\mathrm{X}$ \\
\hline Training Workshops & & & $X$ & & $X$ & $X$ & \\
\hline Public Library & $X$ & & & & & & \\
\hline Personal Library & & & $X$ & $X$ & $X$ & & $X$ \\
\hline Conferences & & $X$ & $X$ & & $X$ & & \\
\hline Internet & $X$ & $\mathrm{X}$ & $X$ & $X$ & $X$ & $X$ & $\mathrm{X}$ \\
\hline Newspapers & & $X$ & $X$ & & $X$ & & $\mathrm{X}$ \\
\hline Seminars & $X$ & & $X$ & $X$ & $X$ & $X$ & $X$ \\
\hline Other & & & & $X$ & $X$ & & \\
\hline
\end{tabular}


Also, when asked about the use of authentic materials in interviews all teachers answered that they find it important and that they used these materials in the classroom. The fact that most of these teachers never used them during the observation period, and that their lessons mainly focused on language structure could be due to a lack of training in CLT on the part of these teachers. Vinicius' following remarks provide a further illustration of the teacher's inability to relate authentic materials to the students' reality.

For instance in advanced 3, we have one unit, which is about kid's literature. But what happens is that the book, the unit has 10 pages, but 6 of them are useless for us, because they just talk about books that we have not even heard about. So we teachers have to do everything again. We have to prepare classes made by ourselves, prepared by ourselves, because the ones we have in the book really have no sense for our students. The same as in post advance, the first unit, men who know where their bullets are going, it's about hunting deer in the United States, and we don't even have deer here in Brazil. The entire unit is about the rights of hunters, concerning deer population, and another unit was about kangaroos, we don't even have kangaroos here. So we teachers have to work double, we have to prepare everything again. The design the content does not interest the students, we teachers are lost, because we will have to work double, triple to compensate. Students must be interested at least, they must identify with the way tasks are designed, you know. They must feel interested, excited or curious at least, otherwise they don't learn. 
According to participants, textbooks used in the classroom had little to do with the reality of students in Brazil. Some teachers, such as Vinicius, skipped units in the book because he felt they were useless to students due to the subjects. In addition to the lack of teachers' awareness of CLT to properly implement communicative activities in their classroom, there are, other influences in the classroom environment. The data also revealed that the setting in which teaching occurs also presents constraints on CLT implementation. There were four different settings observed in this present research study, public and private high schools, in which English was part of the overall curriculum; franchised schools and local language institutes. Each of these environments presented different challenges for teachers, and, consequently, for CLT use.

\section{Settings in which teaching occurs}

In the review of the literature it was stated that the context in which a phenomenon occurs has great influence on the individuals experiences and perceptions of those experiences. Therefore, it seems logical to assume that teachers' perceptions of CLT use vary according to the setting in which they experience teaching. In the high schools, teachers deal with the curriculum and regulations set by the Ministry of Education. In contrast, the private language institutes deal with their direct administrations. Yellow is a franchised school, with locations all over Brazil, and with its main office located in a different state. Ultramar is a locally owned school and has only one location.

In view of these different settings, there are also different constraints teachers must deal with. Some of these specific constraints are the curriculum prescribed by the Ministry of Education and disciplinary issues due to overcrowded 
classes for the high schools, and administrative decisions made in the private language institutes. However, there are constraints, due to settings, that are shared among all schools.

\section{Common constraints among schools}

Both teachers who participated in the study from the high schools indicated that the difference in student English proficiency levels affected the use of CLT in the classroom. These teachers indicated that schools do not form English classes based on student proficiency, but on their grade level. Therefore, you have students with very little knowledge of English, and you have very advanced students in the same class. Due to this mixed environment, teachers expressed difficulties in adapting activities to the various levels. Angela stated that "students in one class have many different levels. Some have private English courses, and others don't. Students in one class may have very different levels and needs. Therefore, it's hard to adapt to the various levels in one simple class." During Angela's class observation her statement was made clear. Angela was handing back homework assignments with feedback, a student approached her and asked "O.K., professors, o que significa?" (O.K., teacher, what does that mean?) Angela responded "quer dizer bom" (it means good).

Students in high schools advance according to their grades and not English proficiency. Since all students have to learn the same material, teachers felt it was impossible to create a CLT approach that satisfied the learning needs of the different student group levels. The proficiency level of students is also a perceived constraint in language institutes. In a conversation with Marta, who was the director and owner of Ultramar, she mentioned the fact that language institutes are private, and require students 
to pay monthly fees, thus failing students is not in the best interest of these schools. According to Marta, if you fail a student once or twice, they may become frustrated with the learning process and leave the school, which means fewer students and less money. Marta also said that students come to the school with friends; if you fail one, they are moved away from their friends and may feel discouraged or embarrassed. They may also leave the school.

Another perceived constraint shared among all schools was related to class preparation time. Adapting textbooks to students' reality takes dedication and commitment from teachers, who may not always have the time. Most participants had a full schedule, teaching six or more classes each semester. This leaves little time for class preparation. As Marta explained during her interview, "Well, it takes time; it's not so easy. Usually in Brazil teachers have low salaries so we work 6 hours a day. I mean we work mornings, afternoons, and evenings. You can imagine that, usually, teachers have around 10 classes a week. If you prepare all these classes in a different way, it's a problem; it takes a lot of time."

In addition, creating an environment in which students can use authentic materials that are related to their reality is a difficult task for teachers. As Anita said, "it depends a lot on the work of the teacher, on how experienced the teacher is, on how motivated he is to get involved with the processes that are going on in class." Marta adds that, also, "it can be very hard for teachers who don't have cultural background in the target language. It is also difficult for the teachers who haven't lived abroad to create an environment, which they haven't seen before." The lack of class time preparation was also observed in Li's (1998) study. According to participants of Li's study, preparing CLT activities 
required too much time, and "most of the teachers were already overloaded, any additional work was a burden for them" (p. 689). Li also reported that teachers "lack of time for and lack of expertise in developing communicative materials had been constraints for them [teachers]" (p. 689). It was easy to identify preparation time when observing classes. Teachers that spent more time preparing for classes had more interactive activities.

In this study class preparation time had an impact on classroom activities. Rita, for example, teaches 4 classes in a row 3 times a week, with about10 minutes of interval in which she must walk from one side of the school to another. Rita's schedule was extremely demanding, due to time and class size. Vinicius also had a full schedule, teaching 10 classes, and tutoring 4 additional students. Vinicius and Rita's classes had no communicative activities and used no authentic materials. Given the activities in the classroom, completion of book exercises, and random grammar explanations, it was perceived that these teachers spent very little time preparing classes. Marta also had a full schedule, teaching about 10 classes a week, in addition to her duties as the school director. However, Marta's classes were filled with communicative activities, and always had authentic materials. Therefore, as it will be presented later in more detail, time preparation seemed like a valid constraint for teachers, however, dedication and motivation also had an impact on teachers, as was clear with Marta's classes.

\section{Constraints in high schools}

The high schools in Brazil must follow the regulations of the Ministry of Education. In many cases these regulations do not advocate a CLT approach to foreign language teaching. Such as the 1997 revised national curriculum report from the 
Ministry of Education, which explicitly called for a reading approach to foreign language teaching. An excerpt of the revised national curriculum is presented below:

Deve-se considerar tambem o fato de que as condicoes na sala de aula da maioria das escolas brasileiras (carga horaria reduzida, classes superlotadas, pouco dominio das habilidades orais por parte da maioria dos professores, material didatico reduzido ao giz e livro didatico etc.) podem inviabilizar o ensino das quarto habilidades comunicativas. Assim, o foco na leitura pode ser justificado em termos da funcao social das LE no Pais e tambem em termos dos objetivos realizaveis, tendo em vista condicoes existentes. (Celani \& Lopes, 1997) It must be taken into account the conditions of the majority of the high school classrooms in Brazil (school hours, overcrowded classes, teachers poor oral proficiency level of English for the most part, materials available are reduced to chalk and books etc.) may invalidate the teaching of the four skill areas of communicative approach. Thus, the focus on reading is justified in terms of social function of foreign languages in the country, and also in terms of real objectives, in view of the existing conditions.

The Ministry of Education advocates a focus on reading. Therefore, high school teachers perceived reading as the ideal approach to foreign language teaching because it meets the needs of students. Angela remarked that "students' needs do not meet CLT goals." She further added, "spoken English is not necessary for these students. They will not travel, and they will not use English. Maybe only for reading of books and materials." For this reason Angela felt CLT was not the appropriate teaching approach for her students, and she concentrated more on reading activities. Another reason for 
choosing a reading approach rather then CLT is the required preparation for vestibular, the entrance exam for all universities in Brazil. This exam covers all areas of knowledge, including a foreign language. Students can choose from many languages, including Spanish and English. This exam tests students reading and comprehension of materials in a foreign language and not speaking proficiency. Rita agrees with Angela and stated that "the schools prepare students for the vestibular which, in turn, requires reading proficiency." Rita also said that the university entrance exam requires students to "read texts in English, and answer questions in Portuguese. I teach reading, not English." An observation of Angela's class revealed the method in which reading was approached in the high school classroom.

It is 9:00 P.M., Angela and I just walked in her English class, after walking up 5 flights of stairs. The weather outside is vicious, we can hear the loud wind, and feel the heavy air. It is not yet raining, but the black clouds and thunder give a strong indication that it's going to storm. Students are walking around the classroom, some students are at the windows watching the storm grow. Angela places her material at the teacher's desk in front of the class and I make my way to an empty seat in the back. Angela waives her arms in the air, and says shhh, trying to quite down the students. Students take their seats. Angela explains in Portuguese that today they will read a short text in English on the topic of igloos. Angela distributes the handout, which consist of a 15 line text entitled I Live in an Igloo. The handout also has two exercises, in Portuguese, one is a multiple-choice exercise on vocabulary meaning, and the other is a true or false exercise on the content of the text. As students receive the handout the 
out. It's about 9:08 P.M., students start to yell and cheer. Some students get up and go to the window to watch the storm. It is now raining. We can hear students from other classes also yelling. Angela walks to the hallway door and stood with her arms crossed. Some students start talking on cell phones, and others form small groups to talk. There is mass confusion in the class, and Angela continues to stand at the door. At 9:20 P.M. the lights are still out, Angela tries to quiet down the students, and says the handout activity will be for homework. Angela begins to read the text aloud. Students continue to be noisy, and walk around the classroom. Angela stops reading, and reminds students to work on the handout for homework. Rain starts to fall vigorously. Angela goes to the window to watch the rain with some of the students. At 9:34 P.M. the lights finally return. Angela asks students to return to their desks. She once again reminds students to complete the handout as homework. At 9:50 P.M. the bell rings, class is over.

Angela's class seems to reflect the reality that high schools face in Brazil, as described in the national curriculum, and that justified the reading approach to foreign language teaching. Both Rita and Angela reported that overcrowded classes, and, as a result, disciplinary issues prevented them from implementing CLT activities. According to Rita, “in a large group of students there are more influences, and it's hard to control what students are doing." In addition Rita remarked that the size of classes in high schools imposes a major problem when attempting to implement CLT activities, explaining that "it's impossible [CLT in EFL environments], it's interesting, as long as the number of students in the classroom is reduced, it's impossible with the number of 
students we have, we have 45 students in class." Angela also seemed to agree when she stated that "there are too many students in the class, it's hard enough to get them to read, I can only imagine trying to do role play. It would be impossible for me to assist all the students."

Research done on the topic CLT and class size (Johnson \& Arena, 1995) revealed that teachers have various concerns when dealing with large classes. According to Johnson and Arena (1995) some of the concerns teachers expressed included:

Teachers tended to worry about not being able to give individual attention to students, especially in oral communication activities. Teachers were concerned about control and discipline in large classes and not being aware of everything taking place, especially in oral communication activities. Teachers felt that they could not evaluate all assignments; both those written at home and those produced in oral communication activities. Teachers also felt uncomfortable about having to speak to large numbers of students (p. 1). Specifically, Li (1998) and Burnaby and Sun (1989) indicate in their studies that teachers perceived class size as a limitation for implementing CLT in schools. Li explains that teachers found it difficult to use CLT because of class management. They reported three major problems with class size, noisy classes, teacher difficulties in providing individualized attention to students, and not enough space in class for students or teachers to move around. In Burnaby and Sun (1998) teachers also expressed difficulties in "using communicative methods with large groups" (p. 229). In addition to this limited physical space and overcrowded student presence, many other issues come into play at high schools. It was observed, and remarked by the participants in this study, that large 
classes present an additional challenge to teachers with regard to student behavior. The following is a description of a high school class observation:

It is now 9:30 A.M.; Rita and I are walking to class together. She is talking to me about my study, when the bell rings. She picks up the pace and enters the classroom. Students are noisy, and talking. Some students are sitting on top of their desks, others are walking around, and some are laughing aloud in small groups around the room. The bell has finished ringing, and students don't move. Rita places her material on the teacher's desk, and I squeeze between students and desks to find an available spot to sit. Rita continues to stand in front of the class, and none of the students have altered their position. It is now 9:37A.M., and Rita starts asking students to get to their seats and to be quiet. Students begin to move around. Rita turns to the board and begins to write some phrases in English. Students are extremely noisy. It is now 9:50 A.M., and Rita has not been able to calm down the class. There are two students that are laughing aloud and with their backs to the front of the class. Rita calls their attention, and they answer back at her. She asks the students to leave the class immediately. Another student begins to laugh at the situation. Rita asks him to leave as well. He gets up and starts dancing around making his way to the door. It is now 10:00 A.M., and Rita lectures the students on their behavior. She talks about the importance of foreign language. She tells students that they are acting childish and that they must behave according to their age. It is now 10:13 A.M.; Rita turns back to the board to continue the class. Some students start laughing and whispering to each other. Rita asks one student a question; he doesn't have 
his book on his desk. Rita asks him to open his English book. Other students in the class begin to laugh, and talking begins. Students once again are loud. Some students get up and start walking around the class. Rita stands in front of the class with her hands on her hips, and with a frown on her face. Students ignore her. Rita begins to lectures students once again on their behavior.

Finally the bell rings.

Both high school teachers participating in this present study reported that disciplinary issue was a major problem when attempting to use CLT in the classroom. Harmer (1991) dedicates a whole section in his book on disruptive behavior, where he writes about the different causes of discipline problems and possible solutions. He indicates that "there seems to be three possible reasons for discipline problems: the teacher, the students and the institution" (p. 249). Harmer lists several things teachers should "not do if they want to avoid problems," (p. 249) some of the things he listed include don't go to class unprepared, don't give boring classes, and don't have a negative attitude towards learning. Some of the reasons given by Harmer (1991) on why students behave badly include the student's attitude and a desire to be noticed. As the previous excerpt demonstrates, high school classes had major problems with discipline. The teacher, Rita, appeared embarrassed about the behavior of her students, and said that the discipline problem has been getting worse throughout her years of teaching. She added that it's hard to control the class:

So it becomes another problem because the teacher has to constantly interrupt the class to give lectures on good manners, or etiquette, and removing students from the class, and that becomes very hard. And we end up losing 
the continuum of the activities you are developing, so I feel that lately we are failing as a school because lately we are constantly fighting with students, rather than having pleasure or making them feel the pleasure of learning.

Rita also said that when she tried using CLT in the classroom the disciplinary problem got worse and prevented her from conducting class at all. It disrupted not only her class, but also classes going on around her. Rita remarked during her interview: I remember that when we tried to use communicative approach we were always in conflict with the discipline sector, it's not possible to be that way because the class becomes disorganized and messy, as much as you try to make a class, let's say a class that is not agitated, it becomes agitated because it's new to the students when he is speaking in another language. When they are trying to communicate in another language they get rowdy. They want to show this so it becomes agitated, loud, so I think that the school system structure does not allow it [CLT use].

The above statement concurs with Li's (1998) findings. According to Li, teachers in South Korea also had problems with discipline when attempting to use CLT. Teachers in Li's study remarked that "when everyone starts to talk, the class can be very noisy. Teachers and students in nearby classrooms will complain about the noise in the English class" (p. 692).

In his book The Practice of English Language Teaching (1991), Harmer explains various aspects of classroom management. Among others, he reports that class size influences student's behavior, and learning. Harmer briefly explains that the ideal 
classroom would have 15-20 students, and that 30 students in class will cause significant changes in teacher planning.

The disciplinary problems described above were not observed in the language institutes. In addition, the language institutes did not have to deal with overcrowded classes, since in most classes there was an average of 10 students. However, the language institutes had to deal with other constraints when attempting to implement CLT.

\section{Constraints in the language institutes}

There are two very distinct settings in the private language institutes. Yellow is a franchised school, whereas Ultramar is locally owned and directed. This brings into question the flexibility teachers have to adapt materials. At Yellow, teachers must follow the textbooks provided by the main office, located in another state. According to Roberto, from Yellow, "sometimes we receive things from the home office, and we have to follow them. But teaching and following the book are different things, and this case I think that the materials we use here interrupt our actions as teachers." Most of the classes at Yellow were not student-centered, but in fact, book-centered. In addition, teachers seemed trapped with working exclusively with the textbooks. Roberto remarked that his previous experience as an English teacher was more flexible, and therefore, allowed for the use of other resources. He said:

My previous experience was at the university, and there I had freedom enough to not use the book, for example, and my task was easier let's say. Here I have to use the books and sometimes the content of the book is not that authentic. What do I mean by authentic, they are not relevant for those students, 
maybe for one group it's relevant, and for another group it isn't. And in the university I could adapt that, here I have to be connected to the book."

The use of the book and materials provided from the school also reflect the school curriculum and choice of materials. Not using these materials jeopardizes the credibility of the method used by the school, and thus, presents significant problems for the administration. Anita, who was also the coordinator at Yellow, remarked during her interview that:

I think books and methodologies must be respected, I think that if the school choose this book or if I choose this book its because I trust it. I trust the order it develops and the content. But at the same time to have an authentic class and an original meeting with the students, we always have to adapt here and there, you don't have to change necessarily, but adapt. That is what we do here; we adapt lessons starting in a different way, making different exercises. The book seems to be one route the teacher has and it's good to keep an eye on it in order not to get lost. You know, but it's not the most important thing, because I suppose if one teacher is teaching this or that level it doesn't matter what level, this teacher must be prepared, this teacher, at least theoretically has conditions to teach even without a book. So the book is one guide for the teacher, like the teacher is one guide for the students.

Roberto stated that using the book shows the administration and students that they are working, "it's something we need to have so they [management] and students can see we are working." Roberto's remark seems to suggest the underlying philosophy - a bookcentered class - of Yellow. 
In contrast, at Ultramar, the situation was different. During an informal conversation with Marta, who is also the director of the school, she explained that she selects the books with the help of other teachers at the school. Even though students at Ultramar also paid fees, the teachers and directors were more flexible in meeting students' changing needs. If students have problems adjusting to books, Marta explained that she is flexible and will change the book. She said that, in fact, the previous semester something like that had happened. "I had an intermediate group with mostly teenagers, in which I had selected a very colorful book filled with pictures. Students wanted something more mature, they didn't want pictures, 'pictures are for kids, they are grown ups.' So I searched for another book, and we changed it. Students were happier, and seemed more interested in the material. But the book is just one tool used in the class; I use a lot of other materials."

The use of authentic materials was always present at both Marta's and Fernando's classes at Ultramar. This use of extra materials seemed to follow the general belief and curriculum of the school. The slogan of Ultramar reads, English with Art, and Marta emphasizes the use of art and culture when teaching English. According to Marta, art is a tool for students to relate to the culture of the target language, which in turn will help them learn more easily. Throughout the school, as previously described, Marta had cultural and art artifacts. These artifacts seem to engage students in the general culture of the target language. In many occasions when I entered the school, students were reading posters, and art displays. There was one poster in the computer room that described the perfect job, students read and make jokes about it in the target language. There were also posters of American sports, such as football, and baseball. Students were also playing 
with musical instruments that sat on the table in the lobby area. Some students studied the American maps that were available in the lobby, trying to quiz each other on the fifty states. The whole school seemed to be a cultural center where students were not only exposed to the language, but also the culture and art of the target language. Marta remarked in her questionnaire that "culture is very important when you teach a language." Marta explained that language and culture are connected, and "if we expect students to learn another language," it is necessary to teach culture so students can relate to the target language. She also added that "it can be very hard for teachers who don't have the appropriate cultural background. It is also difficult for teachers who haven't lived abroad to create an environment which they haven't seen before." This philosophy of teaching was part of the whole school, including the curriculum of Ultramar. Fernando remarked during his interview that students "want more than just communication and grammar, they want to be part of the language and the culture, they want to learn how people live." The connection between teaching language and art is also noted in Savignon (2001), where she states that art is a valuable tool for teachers to help students relate to the target language. Ultramar's emphasis on culture and the use of art to effectively teach language provided students with an experience of the language, through communicative interactions. As described previously, Marta transformed her classes into the setting of the target language, and with the use of authentic materials and her creativity, allowed students the opportunity to interact in simulated target language-like environments.

Therefore, it appeared during Marta's classes, as well as Fernando's, that the book was one element of the class and not the focus. During class, Marta would bring bags of 
supplemental materials, such as authentic artifacts and handouts. Fernando also used other materials; once I saw him use cell phones in a class to practice phone conversations. Students literally called each other. In another class, Fernando used a ball to play a game with students using vocabulary words they had learned in a previous class. The problem of book-centered classrooms seemed specific to franchised English schools that received materials from the home office and were required to follow them.

As shown in the data, there seems to be two main areas of concern in the schools participating in the study, (1) teachers awareness of CLT principles, and (2) the setting in which teaching occurs. Teachers in this study seemed to perceive CLT as an acceptable and useful methodology in their classrooms. However, most lacked the training to properly implement communicative activities in their classes. Further, most of them were restricted by the educational system in which they were teaching. The following chapter will give a detailed discussion of the data here presented. 


\section{Chapter 5}

\section{Discussion}

Two main areas of concern were revealed in the findings: teachers' awareness of CLT principles and the constraints of the settings in which teaching occurs. In order to implement an affective CLT approach in the classroom, teachers must begin by understanding the demands and procedures of the approach to be used. The data revealed that teachers, with the exception of Marta, failed to understand what was required of them, and, thus, failed to provide opportunities for communicative interactions and activities in their classrooms. The classes observed were filled with isolated activities outside of any cultural or linguistic context of the target language. In addition, the settings in which teaching occurred presented specific constraints for teachers. In most cases teachers failed to adapt to their settings, thus causing their classes to be nonengaging to students.

\section{Teachers' awareness of CLT principles}

It seemed that most teachers lacked full understanding of CLT principles, which in turn, resulted in unchallenging classes to judge from students' behaviors and attitudes. Many of the teachers remarked on the gap between CLT theories and putting them into practice in the classroom. Most teachers agreed that the limited training they receive is focused on theory and does little to direct them on how to implement such theories in practice in the classroom. As the data revealed, the classes observed included mostly explicit grammar teaching, reading comprehension, and book focus. Teachers, with the exception of Marta and Fernando, failed to provide opportunities for students to interact and use the target language. According to Deckert (1987) the "classroom is a place to 
use the foreign language, and not essentially a place to learn right answers" (p. 19). As the data revealed most of the teachers conducted their classes as a question and answer session, in which they provided students with correct answers.

Teachers also seemed unaware of their roles, and their student's roles in CLT. According to Breen and Candlin (1980) the roles of the teacher is to "facilitate the communication process between all participants in the classroom" (p. 99). Similarly, Xiaoju (1984) points out that “the communicative teacher's role is neither to give lectures nor to supply correct answers...the teacher's job is only to provide the conditions for this [communicative] process, set it going, observe it, try to understand it, give guidance, help it along, analyze and evaluate it" (p. 10). Thus, one of the central roles of the teacher is to provide guidance, to students, during communicative activities. The communicative approach shifts the classroom from a teacher-centered environment to a student-centered one. Therefore, students should be active participants in the classroom and should be provided with great amounts of communicative opportunities for negotiation. Deckert (1987) adds that "real uses of language, especially social uses, are the new priority" (p. 17). As a result, students need guidance from teachers to meet the demands in the new classroom environment in order to properly function in CLT. However, most of the teachers took on the role of provider of correct answers to book exercises, placing themselves as the center of information resource, rather than allowing students to utilize their own knowledge and that of their classmates. As a result, the teachers failed to guide students appropriately to take their roles as negotiators.

Even though most teachers, such as Anita, remarked on the value of communicative interactions, class observations showed that the teachers did little to incorporate 
communicative activities in the classroom. Also teachers perceived the materials and textbooks used in the classroom as an additional constraint for the proper implementation of CLT.

Generally, FL textbooks and materials contain information about and reflect the FL culture, so that students can become proficient in FL culture. However, most teachers perceived that the materials used in the classroom, such as textbooks and audiotapes, was one of the causes for failed attempts of CLT since they did not relate to the students' reality. For example, Vinicius said “if students don't know or have never lived one similar experience, there is no use talking about things, because they will forget soon, and they will not find any use for this." However, adapting materials to students' needs is the role of the teacher. Perhaps, teachers lacked the necessary training and understanding of CLT to properly adapt and integrate materials in their classes. In fact, teachers seemed not to know how to provide background knowledge to students so that they could relate acquired new knowledge to the knowledge they already had. According to Omaggio (2001), "for material to be meaningful, it must be clearly relatable to existing knowledge that the learner already possess" (p. 144). Teachers recognized the importance of background knowledge, as seen in Vinicius previous statements, however, they failed to incorporate or provide students with such knowledge. In most cases, like Vinicus himself acknowledged, unites in the book were skipped because students did not have the background knowledge to relate to the topics covered in the unit. It appears that teachers' lack of training prevented them from providing students with the necessary background knowledge in order to relate to new materials and topics. 
The teachers themselves did not recognize their own lack of awareness of CLT principles. As a consequence, they perceived their classes as communicative and effective. However, observation of students' behaviors revealed that, in fact, classes did little to engage them in the learning process. Students, in many cases, appeared distant from the classroom by looking around, and talking about unrelated issues in the classroom. In addition, students misbehaved and caused a constant interruption during teaching. According to Gardner (2001), "if the language teacher is ineffective or non-responsive, or, if the course is particularly dull or confused, etc., these factors will undoubtedly be reflected in the individual's attitudes towards the learning situation" (p. 8). Perhaps because teachers were unable to realize what the origin of the problem (i.e., students' disruptive behavior) was, they attributed it mainly to class size, and never to the nature of the lessons they presented in the classroom. Therefore, students' behavior and attitudes appeared to reflect the reality of the classroom, which consisted of mostly meaningless activities. Creating a class in which students can feel challenged and able to put their English knowledge to practice would lead to an increase in motivation.

In addition, student behavior, as reported previously, reveals that present teaching methods may not be effective. The descriptions of disruptive classes paint a clear picture of the present conditions in Brazilian high school English classes. Students have a negative attitude towards English learning, and teachers, by providing non-engaging classes, add to their poor behavior. According to Harmer (1991) there are various things teachers should avoid in order to prevent disruptive behavior, including not giving boring classes: "it seems true that perhaps the 
greatest single cause of indiscipline is boredom" (p. 250). Therefore, it seems that if teachers provide a more engaging and enjoyable environment for language teaching, students may feel more challenged to learn. However, it was apparent that teachers participating in this study were not able to do that.

Besides the fact that teachers gave unchallenging classes, it has been shown by research that the setting in which teaching takes place also plays an important role in student behavior. The following section reports the different settings that were observed in this study. In addition, the section discusses the various constraints that each setting presents for CLT implementation.

\section{Setting in which teaching occurs}

The data revealed that the setting in which teaching occurs imposes many constraints on teachers. Related to the issue of setting, is the issue of teaching load. The reality is that teachers in Brazil are overworked and underpaid. Therefore, in order to make a living, most teachers have an average of 10 classes to teach each week, which imposes great constraints on class preparation time. Therefore, creating a fully communicative environment, in which they are expected to use authentic materials, and provide opportunities for communicative interactions, may not be realistic, since preparation is time consuming and difficult for teachers. As Anita said, "it depends a lot on the work of the teacher, on how experienced the teacher is, on how motivated he is to get involved with the processes that are going on in class." In fact, only two teachers, Marta and Fernando, were able and motivated enough to create communicative activities for their classes. As expected, teachers that spent more time preparing for classes had more interactive activities, as was the case of Marta and Fernando. 
Although time preparation is an important factor in accomplishing the goals set by CLT, teacher motivation seems to play an important role as well. After careful analyses of the data, it was apparent that many teachers lacked the motivation to spend the appropriate time for class preparation and for proper development of communicative activities. Marta stated that "there are two sides, you can be one teacher that tries your best to motivate your students, to make your students want to speak English as natural as possible, and you have those teachers that they just follow the books and students just learn that artificial English just for them to pass on tests and get the work done." The analysis of the data seems to indicate that the decision of the participants to belong to one group or the other depends on the salaries and on the constraints imposed by the school settings.

Therefore, it is important to mention the situational difference between Yellow and Ultramar. As mentioned previously Yellow is a franchised English school, with locations all over Brazil. In contrast, Ultramar is a small locally based English school. It appeared that the motivation of teachers in Yellow was lower, and that teachers mostly focused on the textbook, perhaps due to the way the franchised school is organized. Each level has a textbook and a workbook that is chosen by the home office in another state and the teachers must follow it whether they like it or not. Teachers have to finish the book by the end of each semester in order for students to move to another level. This pressure forces teachers to focus primarily on the work and on finishing all the exercises of the book during class time. In contrast, in the small English school the situation was quite different. During observations of the teachers working there, Marta and Fernando, it was apparent that the book, chosen 
by them on the basis of students' needs, was more of a tool during classes rather than the focus. This flexibility allowed them to create activities that provided students with opportunities to use the language for real purposes.

In addition, it is important to point out that Marta had a strong motivation to succeed. Not only did Marta have the necessary background knowledge and experience to achieve a more creative and communicative classroom, she was also motivated by the fact that she was the director and owner of Ultramar. Being the owner of the school affected Marta's to the extent of obtaining excellent results in her classroom. Keeping students happy and satisfied with the teaching methodology, textbooks, and materials was a priority for Marta. Therefore, using authentic materials and keeping students interested and engaged in the classroom provided a stronger school. As a consequence, students had the advantage of experiencing a truly communicative classroom, with many opportunities for communicative interactions.

In contrast, teachers at Yellow employed by the school had little motivation to go beyond the requirements of completing the textbook assigned. All the classes at Yellow were centered on the book; the book went beyond a tool to guide teachers and was the focus of the whole class. In fact, all of Vinicius classes focused on completing book exercises, which, in turn, limited the communication and interaction opportunity among students. In this situation, I observed that the use of the book, and the pressure to complete the book by the end of the semester was part of school policy. As Roberto previously stated, completing the book and working on book exercises shows the administration and the students they are working. In addition, the school policies did not encourage teachers to provide supplementary materials, or use 
authentic materials to provide students with opportunities for communicative interactions. Since students were required to buy these books, teachers in turn had to use them in their entirety. Changing the book or not using the book would bring into question the whole curriculum of the school, and would cause problems for the administration. In many ways, according to Marta, "language teaching is a business rather than a process of experiencing a different culture and language."

On the other hand, at the high schools the constraints were quite different. Teachers at the high school worked in a more academic system; thus, English was part of the overall curriculum. Teachers in the high schools are required to follow the national curriculum guidelines, which advocate a reading approach to foreign language teaching. In addition, the national curriculum states that communicative competence is not a goal of foreign language teaching in Brazil because, in their view, it doesn't meet the needs of students. The national curriculum also emphasizes that teachers need to prepare students for the university entrance exam, which tests reading comprehension. Therefore, a communicative approach to teaching is perceived as unnecessary, causing teachers to avoid its use.

Another constraint perceived by teachers is the classroom setting, which mostly consists of overcrowded classes. Due to the large number of students, an average of 45 per class, teachers seemed to have problems implementing communicative activities. In addition, students in the high schools presented many problems with discipline. Teachers perceived that the disruptive behavior of students would worsen if communicative activities were to be implemented. In fact, Rita suggested that when she did attempt CLT activities students became noisy, and 
caused disturbances in neighboring classes. This disciplinary problem, added to the fact that teachers had an overload of classes, discouraged teachers from attempting to use communicative activities in their classes.

Although the data revealed various constraints in classroom settings, and as a result, students disruptive behavior and lack of interest in the target language, it is still the issue of teachers' awareness of CLT principles that caused the lack of communicative activities in the classrooms observed. According to Harmer (1991), even under unfavorable conditions, such as disruptive behavior from students or constraints imposed by settings, successful results in English teaching can occur. However, that would require expertise on the part of the teacher.

\section{Summary}

Teachers lack awareness of CLT principles, thus affecting their teaching in the classroom. High schools and language institutes, unfortunately, impose additional constraints on teachers, which also affect language teaching, such as completion of textbooks, abiding by methodologies imposed by the Ministry of Education. Finally, teachers themselves have little motivation to adjust to the settings in which they teach and to use authentic materials and communicative activities properly, due to the fact that they have little time for class preparation given their workload and little motivation due to their low salaries. Therefore, it seems that in the end students are the ones to pay the price. 


\section{Chapter 6}

Conclusion

If there is harmony between (a) the student (in terms of style and strategy preferences) and (b) the instructional methodology and materials, then the student is likely to perform well, feel confident, and experience low anxiety. If clashes occur between (a) and (b), the student often performs poorly, lacks confidence, and experiences significant anxiety. Sometimes such clashes lead to serious breakdowns in teacherstudent interaction. These conflicts may also lead to the dispirited student's outright rejection of the teaching methodology, the teacher, or the subject matter (Oxford, 2001, p. 359).

The clashes that Oxford alludes to in the previous citation summarize the findings of this research project quite accurately. The aim of this study was to investigate teachers' perceptions of CLT use in Brazil. After careful analysis of the data, a few conclusions can be reached based on the perceptions of the teachers participating in this study. The data revealed that four schools, with very different settings, presented significant constraints when attempting to implement CLT. In addition, the data also revealed that teachers' awareness of CLT principles also prevented them from properly creating and developing communicative activities. Finally, it was perceived that CLT use in Brazil could be successful, since at least one teacher participating in this study presented significant success with the use of CLT in her classroom.

The data revealed that the teachers in Southern Brazil do not have enough understanding and training in CLT. Teachers remarked that the training they received, if 
any, was focused on theoretical aspects of CLT, and gave little direction on how to implement such theories in practice in the classroom. The analysis of the data also indicated that due to the lack of training and understanding of CLT, teachers couldn't deal with the complexity of classroom interactions prescribed by the communicative approach to language teaching. Adapting materials, dealing with classroom conditions, and creating communicative activities were some of the problems teachers encountered. Marta was the only teacher that seemed to overcome some of these problems and presented a true communicative class for her students. On the other hand, the remaining teachers failed to recognize their training handicap and as a consequence, presented failed attempts to create communicative classes.

In addition, teachers' awareness of CLT principles was also perceived as a constraint. Teachers failed to recognize their own misconceptions about CLT principles, thus, preventing them from properly implementing communicative activities in the classroom. Although most teachers remarked that they had plenty of opportunities for training, and free access to authentic materials, with the exception of two teachers, none seemed to know how to incorporate communicative activities in their classrooms. In addition, teachers seemed unaware of how and when to use CLT. Some teachers perceived CLT as only useful for beginning level students. Others seemed to believe that pair or group work on book exercises were communicative activities. Still others were unable to incorporate communicative principles to reading activities. These were mostly due to teacher's lack of training and understanding of CLT principles. Although most teachers had a basic understanding of the theories of CLT, most did not know how to put 
such theories into practice. Finally, teachers' lack of training was also perceived through their class management skills, and their ineffective activities in the classroom.

Another conclusion that can be drawn from this study is that teachers in Brazil have various constraints when attempting to implement CLT due to the environment in which their teaching occurs. At the high schools teachers had to follow predetermined national curriculum provided by the Ministry of Education. This national curriculum advocated a reading approach to English teaching, and shunned CLT because, as they remarked, CLT does not meet the needs of Brazilian students. According to the national curriculum, students do not need to develop their communicative skills, but in fact reading comprehension. In addition, teachers at the high schools need to focus on preparing students for the university entrance exam, which test reading comprehension, as prescribed by the national curriculum. This attitude discourages teachers from attempting CLT. Another constraint teachers must deal with at the high schools are problems with large classes and students disruptive behavior, which in many cases prevents teaching all together.

The language institutes, unlike the high schools, do not have to follow the curriculum set forth by the Ministry of Education. However, teachers at the language institutes face their own share of constraints when attempting to implement CLT. In the study there was two different types of language institutes, Ultramar, locally owned and operated, and Yellow, a nationally franchised language institute. At Ultramar teachers were more flexible in adapting textbooks and using extra materials. In addition, at Ultramar, teachers used an extensive amount of authentic materials and realia to create communicative activities and to provide students with opportunities for interactions. 
The fact that Ultramar is a business cannot be ignored, however, the teachers and students seemed more motivated and were encouraged to explore English teaching and learning. On the other hand, Yellow, which was a nationally franchised language institute, received materials from their home office. Teachers were obligated to use materials provided by the schools. In addition, the school expected teachers to complete textbooks by the end of each semester. Teachers perceived the use of the textbook as a tool for students and school administrations to track their work. Teachers at Yellow were not encouraged to adapt or complement their textbook. In fact, none of the classes observed at Yellow had anything more than a textbook, and no authentic materials were used at any time. In addition, the teachers limited themselves to using the textbook, and completing book exercises. None of the teachers at Yellow provided students with opportunities to develop their communicative competence through interactions.

Finally, it can be concluded through this study that in CLT use is effective and possible in Brazil, in at least two situations. At Ultramar both teachers used communicative activities in their classrooms. In addition, Marta, one of the teachers, presented several examples of creative activities that provided students with opportunities to interact. Marta also used authentic materials effectively and engaged students successfully in role-play activities. The school itself seemed to focus on creating an environment in which students had many opportunities to use and be exposed to the target language. In view of what was observed at Ultramar, it would we fair to say that CLT use could be effective and possible in Brazil, provided that appropriate conditions exist. Specifically, Marta has a huge motivation for success; therefore she puts all her effort in providing students with an authentic experience of the target language through 
communicative interactions. On the other hand, most teachers in Brazil have low salaries and large workloads, which could be a main constraint in the use of CLT.

\section{Limitations of the study}

The fact that students were not interviewed or questioned limited the analysis of the data. Although some of the students' reactions were observed and noted during class observation, a more in-depth investigation of students would have benefited the overall results of this study. Students' perceptions and reactions to classroom activities would be beneficial in the overall understanding of teachers' perceptions.

\section{Implications of the study}

This present study is consistent with existing research findings in the topic. Li (1998), Burnaby and Sun (1997), Gorsuch (2000), and Altan (1995) found similar constraints and difficulties in the settings in which they conducted their research. Most of the studies agree that constraints with national curriculums, materials, and teacher's lack of training prevent the proper implementation of CLT activities in the classroom. This implies that the way in which CLT is used in ESL settings may not be the most appropriate way for it to be used in EFL setting, mostly due to these foreign countries own realities.

Furthermore, this study, like findings in previous research, implies that teachers in Brazil need more training and understanding for how to implement in practice theories they learn at the universities, English workshops, seminars, and conferences. In addition, teachers need to observe classes in which CLT use is effective, in order for them to see it in action. 
Another implication refers to the teaching materials and school administration. Teachers need to have more flexibility to use authentic materials and to complement the textbooks used in the classrooms. Although proper training in how to use authentic materials is necessary, having them as options will help teachers create a more communicative setting for their students.

\section{Further research}

As I conducted this study it became apparent that there were many questions left unanswered, which would serve as research questions for other studies. Some of these questions include (1) what are students' perceptions of CLT use in Brazil? This answer would provide valuable information for teachers and assist them in implementing a communicative approach in their classrooms. (2) What are the perceptions of administrators of teaching methodologies used in Brazilian classrooms? The answer to this question will provide a clear understanding of the perceptions and expectations of administrators that operate language institutes. (3) What kind of guidance and training are provided to teachers at English workshops, conferences, and seminars in Brazil? This information will help access the lack of awareness of CLT principles and will provide important solutions for existing limitations of such training sources. (4) What are teachers' and students' perceptions of CLT at the university level? This will bring further information into the field of CLT in EFL settings. In addition, it will present interesting sources of comparison between the university level of foreign language teaching and that of high schools and language institutes. 


\section{Works Cited}

Abbott, G. (July, 1987). Introducing communicative activities gently to reluctant teachers. English Teaching Forum, 25(3), 48-49.

Altan, M. Z. (1995). The culture of the English language teacher in an EFL context. Unpublished manuscript, Inonu University, Malatya, Turkey.

Amores, M. (1997). A new perspective on peer-editing. Foreign Language Annals, 30 (4), 513-522.

Black, M. C. (July, 1997). The best of both worlds: Adapting ESL methodology to the EFL environment. English Teaching Forum, 35 (3), 20-23.

Burnaby, B., \& Sun, Y. (1989). Chinese teachers' views of western language teaching: Context informs paradigms. TESOL Quarterly, 23, 219-238.

Breen, M. P. \& Candlin, C. (1980). The essentials of a communicative curriculum in language teaching. Applied Linguistics, 1, 89-112.

Canale, M., \& Swain, M. (1980). Theoretical bases of communicative approaches to second language teaching and testing. Applied Linguistics, 1, 1-47.

Canale, M. (1983). From communicative competence to communicative language pedagogy. In J. Richards \& R. Schmidt (Eds.), Language and communication (pp. 2-27). New York: Longman.

Celani, M. A. A., \& Lopes, L. P. M. (1997). Parâmetros curriculares nacionais terceiro e quarto ciclos do ensino fundamental. Brasilia, D. F.: Ministério da Educação e do Desporto.

Celce-Murcia, M. (2001). Teaching English as a second or foreign language ( ${ }^{\text {rd }}$ ed.). Bostan, MA: Heinle \& Heinle. 
Celce-Murcia, M., Dornyei, Z., \& Thurrell, S. (1997). Direct approaches in L2 instruction: A turning point in communicative language teaching? TESOL Quarterly, 31, 141-152.

Cook, V. (1991). Second language learning and language teaching (2 $2^{\text {nd }}$ ed.). London: Arnold.

Couto, V., \& Towersey, L. (1992). The Brazilian EFL learner: A profile influencing curriculum. Paper presented at the $26^{\text {th }}$ Annual TESOL Convention, Vancouver, Canada.

Deckert, G. (July, 1987). The communicative approach: Helping students adjust. English Teaching Forum, 25 (3), 17-20.

Dubin, F. (1995). The craft of materials writing. In P. Byrd (Ed.), Material writer's guide, pp. 64-78. Boston: Heinly \& Heinle.

Ellis, G. (1996). How culturally appropriate is the communicative approach? ELT Journal, 50, 213-218.

Fotos, S. (1994). Integrating grammar instruction and communicative language use through grammar consciousness-raising tasks. TESOL Quarterly, 28, 323-347.

Gardner, R. C. (1968). Attitudes and motivation: Their role in second language acquisition. TESOL Quarterly, 2, 141-150.

Gardner, R. C. (2001). Language learning motivation: The student, the teacher, and the researcher. Texas Papers in Foreign Language Education, 6 (1), 1-18.

Gomes de Matos, F. (1968). Foreign language teaching in Brazil. In Sebeok, T. (Ed.) Trends in ibero-American and caribbean linguistics, pp. 468-490. Mounton: The Hague. 
Gomes de Matos, F., \& Pinto, A. P. (November/December, 2000). English language education in Brazil: Progress and partnerships. ESL Magazine, 26-28.

Gorsuch, G. (2000). EFL educational policies and educational cultures: Influences on teachers' approval of communicative activities. TESOL Quarterly, 34, 675710.

Harmer, J. (1991). The practice of English language teaching. New York: Longman.

Hayes, E. (1989). Hispanic adults and ESL programs: Barriers to participation. TESOL Quarterly, 23, 47-63.

Howatt, A. (1984). A history of English language teaching. Oxford: Oxford University Press.

Hymes, D. (1972). On communicative competence. In J. B. Pride \& J. Holmes (Eds.), Sociolinguistics: Selected readings (pp. 269-293). Baltimore: Penguin.

Johnson, P., \& Arena, J. (1995). Students' perceptions of foreign language communicative teaching and class size. Unpublished manuscript.

Kang, S. (October-December, 1999). Learning styles: Implications for ESL/EFL instruction. English Teaching Forum,37 (4), 6-11.

Larsen-Freeman, D. (1986). Techniques and principles in language teaching. New York: Oxford University Press.

Lee, J., \& VanPatten, B. (1995). Making communicative language teaching happen. New York: McGraw-Hill, Inc.

Li, D. (1998). "It's always more difficult than you plan and imagine": Teachers' perceived difficulties in introducing the communicative approach in South Korea. TESOL Quarterly, 32, 677-703. 
Liao, X. Q. (2000). Communicative language teaching: Approach, design and procedure. Unpublished manuscript.

Liao, X. Q. (2000). Communicative language teaching innovation in China: Difficulties and solutions. Unpublished manuscript.

Littlewood, W. T. (1981). Communicative language teaching: An introduction. Cambridge: Cambridge University Press.

Long, M., \& Crookes, G. (1992). Three approaches to task-based syllabus design. TESOL Quarterly, 26, 27-56.

Marshall, C. \& Rossman, G. B. (1999). Designing qualitative research ( $3^{\text {rd }}$ ed.). Thousand Oaks: SAGE Publications.

McGroarty, M. (1984). Some meanings of communicative competence for second language students. TESOL Quarterly, 18, 257-272.

Morley, J. (1984). Listening and language learning in ESL. Orlando, FL: Harcourt Brace Jovanovich, Inc.

Motta-Roth, D., Herbele, V., \& Vasconcelos, M. L. (1995). EFL teaching in Brazil: Emphasizing conditions, processes, or product? Unpublished manuscript, Universidade Federal de Santa Maria, Santa Maria, RS, Brazil.

Nunan, D. (1986, April). Communicative language teaching: The learner's view. Paper presented at RELC Regional Seminar, Singapore.

Nunan, D. (1991). Communicative tasks and the language curriculum. TESOL Quarterly, $25,279-295$. 
Oliveira, L. (2002). The teacher's use of the target language: The perspective of beginning EFL learners. Unpublished master's thesis, West Virginia University, Morgantown, West Virginia, United States.

Omaggio, A. (2001). The role of context in comprehension and learning. In Alice Omaggio (Ed.), Teaching language in context, pp. 139-162. Boston, MA: Heinle \& Heinle.

O’Malley, J.M., \& Chamot, A. U. (1990). Learning strategies in second language acquisition. Cambridge: Cambridge University Press.

Oxford, R. (2001). Integrated skills in the ESL/EFL classroom. ERIC Digest.

Paulston, C. B. (1985). Communicative competence and language teaching: Second thoughts. Selected papers from the RELC Seminar, Singapore, 84, 13-31.

Prabhu, N. (1983). Procedural syllabuses. Paper presented at the RELC seminar, Singapore.

Prabhu, N. S. (1985). Communicative teaching: "Communicative” in what sense? Selected papers from the RELC Seminar, Singapore, 84, 32-40.

Pufahl, I., Rhodes, N., \& Christian, D. (2001). Foreign language teaching: What we can learn from other countries. Learning Languages, 6 (2), 4-13.

Reid, J. M. (1995). Developing ESL writing materials for publication or writing as a learning experience. In P. Byrd (Ed.), Material writer's guide, pp. 64-78. Boston: Heinle \& Heinle.

Richards, J. C., Platt, J., \& Platt, H. (1992). Dictionary of language teaching and applied linguistics ( $2^{\text {nd }}$ ed.). Essex, England: Longman. 
Richards, J. C., \& Rodgers, T. S. (1986). Approaches and methods in language Teaching: A description and analysis. Cambridge: Cambridge University Press.

Richards, J. C., \& Rodgers, T. S. (2001). Approaches and methods in language teaching. Cambridge: Cambridge University Press.

Richards, J., \& Schmidt (1983). Language and communication. New York: Longman.

Rivers, W. (1968). Teaching foreign language skills. Chicago: The University of Chicago Press.

Rivers, W. (1973). From linguistic competence to communicative competence. TESOL Quarterly, 7, 25-34.

Rivers, W. (1978). A practical guide to the teaching of English as a second or foreign language. New York: Oxford University Press.

Rivers, W. (1981). Teaching foreign language skills ( $2^{\text {nd }}$ ed.). Chicago: The University of Chicago Press.

Sano, M., Takahashi, M., \& Yoneyama, A. (1984). Communicative language teaching and local needs. ELT Journal, 38 (3), 170-177.

Savignon, S. J. (1972). Communicative competence: An experiment in foreign-language teaching. Philadelphia: Center for Curriculum Development.

Savignon, S. J. (1983). Communicative competence: Theory and classroom practice. Reading, Massachusetts: Addison-Wesley Publishing Company.

Savignon, S. (1991). Communicative language teaching: State of the Art. TESOL Quarterly, 25, 261-277. 
Savignon, S. J. (1997). Communicative competence: Theory and classroom practice ( $2^{\text {nd }}$ ed.). New York: McGraw-Hill.

Savignon, S. J. (2001). Communicative language teaching for the twenty-first century. In Marianne Celce-Murcia, Teaching English as a second or foreign language ( $3^{\text {rd }}$ ed), pp.13-28. Boston, MA: Heinle \& Heinle.

Scarcella, R. C., \& Oxford, R. L. (1992). The tapestry of language learning: The individual in the communicative classroom. Boston, MA: Heinle \& Heinle Publishers.

Tarvin, W.L., \& Al-Arish, A. Y. (1991). Rethinking communicative language teaching: Reflection and the EFL classroom. TESOL Quarterly, 25, 9-27.

Taylor, B. (1983). Teaching ESL: Incorporating a communicative, student-centered component. TESOL Quarterly, 17, 69-88.

White, R. (1987). Managing innovation. ELT Journal, 41 (3), 211-218.

Widdowson, H. G. (1996). Authenticity and autonomy in ELT. ELT Journal, 50, 67-68.

Xiaoju, Li. (1984). In defense of the communicative approach. ELT Journal, 38, 2-13. 


\section{Appendix A}

Questionnaire

Please complete the following questions as appropriate. Your name will only be used to prepare the follow-up interview.

1. Name:

2. Date: $(\mathrm{M} / \mathrm{D} / \mathrm{Y})$

3. Female ( ) Male ( )

4. Age: less then 18 ( )

$18-24()$ $25-32()$

33 or more ( )

5. How many years have you been teaching English?

6. Have you taught English abroad? Where?

7. What level of education do you have, mark all that apply:

$\begin{array}{ll}\text { High School/ Secundario ( ) } & \text { BA/Superior ( ) } \\ \text { Masters/ Mestrado ( ) } & \text { PhD/ Doutorado ( ) } \\ \text { Training Courses ( ) } & \text { English work shops ( ) }\end{array}$

Intensive English Program Abroad ( ) Other: ( )

8. In what kind of school do you currently teach?

Private English School ( )

Private High School ( )

Private Tutor ( )
Public High School ( )

College preparatory School ( )

Other ( ) 
9. What age group do you teach?

Children under $10($ ) Children between 11-15 ( )

Teenagers between 16-18 ( ) Young adults between 19-25 ( )

Adults between 26-35 ( ) Adults over 36 ( )

10. What is the average number of students in your classroom?
Less then $10($ )
$10-15$ ( )
$15-25()$
$25-35()$
$35-45()$
45 or more ( )

11. How many classes do you normally teach each semester (or quarter)?
$1($ )
2( )
3 ( )
4()
$5($ )
6 or more ( )

12. Do you have access to authentic material from the target language?
Yes ( )
No ( )

Mark sources of authentic materials you use, all that apply:

$\begin{array}{lll}\text { School Library ( ) } & \text { Public Library ( ) } & \text { Internet ( ) } \\ \text { Friends ( ) } & \text { Personal Library ( ) } & \text { Newspapers ( ) } \\ \text { Magazines ( ) } & \text { Conferences ( ) } & \text { Seminars ( ) } \\ \text { Training Workshops ( ) } & \text { Other }\end{array}$

13. How many hours do you spend weekly preparing classes (average)?
Less then $5($ )
$5-10()$
$10-15()$
$15-20()$
20 or more ( ) 
14. Mark the types of activities you use in your classroom:

\begin{tabular}{|l|}
\hline Always \\
\hline Fill-in the blank \\
\hline Silent Reading \\
\hline Role Play \\
\hline Paragraph Translation \\
\hline Action Sequences (TPR) \\
\hline Drills \\
\hline Problem Solving \\
\hline Modeling \\
\hline
\end{tabular}

15. Which best describes the teaching method you use in your classes today?

Translating from Portuguese to English ( )

Translating from English to Portuguese ( )

Memorization of dialogues and choral repetition ( )

Group activities ( )

Interactive activities ( )

Problem Solving activities ( )

16. Have you tried Communicative Language Teaching (CLT)?

Yes ( ) No( )

17. How did you like using CLT in your classroom?

18. Why did you or why didn't you try CLT? 
19. Please mark some of the difficulties you, as a teacher, have faced when teaching EFL?

Deficiency in spoken English ( )

Deficiency in target language culture ( )

Little time to prepare material ( )

Students English proficiency ( )

Students learning styles ( )

Grammar-based needs of students ( )

Large classes ( )

Access to authentic materials ( )

Differences between CLT applications in EFL and ESL environments ( )

No difficulties ( )

20. Have you used other Second Language Teaching Methods? Yes ( ) No ( ) Marks the ones used:

Silent Way ( )

Natural Approach ( )

Total Physical Response ( )

Reading Method ( )

Affective - Humanistic ( )

Communicative Language Teaching ( )
Audio Lingual Method ( )

Grammar Translation ( )

Direct Method ( )

Cognitive Approach ( )

Natural Approach ( )

21. What methods have you experienced as a language student?

22. Please define in your own words Communicative Language Teaching?

23. What is your perception of CLT in EFL environments, such as Brazil? 


\section{Appendix B}

\section{Checklist - CLT in the Classroom}

Checklist of CLT observable behavior, and activities in the classroom:

Student centered environment
Student participation

Teacher participation

Teacher acts as negotiator

Small group discussion

Role-play activities

Use of authentic material from the target language
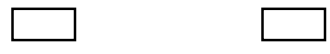

Textbooks used in the classroom are not grammar-based

Target language is used during all class time

Minimal use of native language during the class

Directions for exercises and activities are given in TL

Choral repetition and drills

Oral expression of opinions by students

Students give each other feedback

Focus of activities is content

Correction is minimal from teacher

Teacher lectures to class (Atlas teaching)

Note: 


\section{Appendix C}

\section{Teacher Interview Questions}

The interview is composed of open-ended questions addressing the use of Communicative Language Teaching (CLT) in English as a Foreign Language (EFL) environments. Other questions may be added based on subjects answers to the questionnaire. It will be made clear to all participants that they do not have to answer any questions that they prefer not to answer.

1. How do you feel about using CLT in the classroom?

2. Do you feel that CLT fails to address issues specific to EFL environments?

3. Do you think it's possible to adapt the theories and methodology of CLT into an EFL classroom? How would you accomplish that?

4. In your opinion how do students like CLT activities?

5. Do you feel that teachers in Brazil are encouraged to use CLT?

6. What are some of the difficulties you have faced personally when attempting CLT in your classroom? Were you able to overcome those difficulties? How?

7. Do you feel that students in Brazil would benefit from CLT?

8. When and where were you trained as an English teacher?

9. How do you define communicative competence?

10. Do you feel the literature in the field fails to recognize the differences between EFL and English as a Second Language?

11. Are you given opportunities for retraining and for workshops? 